\title{
Polyphasic taxonomy of the genus Shewanella and description of Shewanella oneidensis sp. nov.
}

\author{
Kasthuri Venkateswaran, ${ }^{1 \dagger}$ Duane P. Moser, ${ }^{1}$ Michael E. Dollhopf, ${ }^{1}$ \\ Douglas P. Lies, ${ }^{1}$ Daad A. Saffarini, ${ }^{2}$ Barbara J. MacGregor, ${ }^{3}$ \\ David B. Ringelberg, ${ }^{4} \ddagger$ David C. White, ${ }^{4}$ Miyuki Nishijima, ${ }^{5}$ \\ Hiroshi Sano, ${ }^{5}$ Jutta Burghardt, ${ }^{6}$ Erko Stackebrandt ${ }^{6}$ \\ and Kenneth $\mathrm{H}$. Nealson'§
}

\begin{abstract}
Author for correspondence: Kasthuri Venkateswaran. Tel: +18183931481 . Fax: +18183934176. e-mail:kjvenkat@caltech.edu
\end{abstract}

1 Center for Great Lakes Studies, University of Wisconsin-Milwaukee, Milwaukee, WI 53204, USA

2 Department of Microbiology, University of Massachusetts, Amherst, MA, USA

3 Department of Civil Engineering, NorthWestern University, Evanston, IL 60645, USA

4 Center for Environmental Biotechnology, University of Tennessee/Oak Ridge Laboratories, Knoxville, TN 37932, USA

5 Marine Biotechnology Institute, Shimizu Laboratory, Shimizu, Japan

6 DSMZ - Mascheroder Weg 1b, D-38124 Braunschweig, Germany
The genus Shewanella has been studied since 1931 with regard to a variety of topics of relevance to both applied and environmental microbiology. Recent years have seen the introduction of a large number of new Shewanella-like isolates, necessitating a coordinated review of the genus. In this work, the phylogenetic relationships among known shewanellae were examined using a battery of morphological, physiological, molecular and chemotaxonomic characterizations. This polyphasic taxonomy takes into account all available phenotypic and genotypic data and integrates them into a consensus classification. Based on information generated from this study and obtained from the literature, a scheme for the identification of Shewanella species has been compiled. Key phenotypic characteristics were sulfur reduction and halophilicity. Fatty acid and quinone profiling were used to impart an additional layer of information. Molecular characterizations employing smallsubunit 16S rDNA sequences were at the limits of resolution for the differentiation of species in some cases. As a result, DNA-DNA hybridization and sequence analyses of a more rapidly evolving molecule (gyrB gene) were performed. Species-specific PCR probes were designed for the gyrB gene and used for the rapid screening of closely related strains. With this polyphasic approach, in addition to the ten described Shewanella species, two new species, Shewanella oneidensis and 'Shewanella pealeana', were recognized; Shewanella oneidensis sp. nov. is described here for the first time.

Keywords: Shewanella, shewanella oneidensis sp. nov. MR-1, polyphasic taxonomy, 16S rDNA, gyrase B

\section{INTRODUCTION}

Bacteria currently classified under the generic name of

†Present address: Environmental Engineering Sciences, California Institute of Technology, Mail Code 138-78, $1201 \mathrm{E}$. California Blvd, Pasadena, CA 91125 , USA.

‡Present address: Dyntel Corp., Waterways Experiment Station, Vicksburg, MS 39180-6199, USA.

§ Present address: Geology of Planetary Sciences, California Institute of Technology, Mail Code 170-25, 1201 E. California Blvd, Pasadena, CA 91125, USA.

Abbreviations: FAME, fạtty acid methyl ester; TMAO, trimethylamine $\mathrm{N}$ oxide.

The GenBank accession numbers for the sequences reported in this paper are given in Table 1.
Shewanella have been a subject for scientific scrutiny for at least 65 years. Members of this genus have long been associated with the spoilage of proteinaceous foods (Shewan, 1977; Jorgensen \& Huß, 1989) and have been implicated as opportunistic pathogens of humans and aquatic animals (Brink et al., 1995; Aguirre et al., 1994). The potential of these organisms to mediate the co-metabolic bioremediation of halogenated organic pollutants (Petrovskis et al., 1994) as well as the destructive souring of crude petroleum (Semple \& Westlake, 1987) have also been considered.

More recently, Shewanella strains have been studied for their involvement in a variety of anaerobic processes including the dissimilatory reduction of manga- 
Table 1. Bacterial strains used in this study

\begin{tabular}{|c|c|c|c|c|c|c|}
\hline \multirow[t]{2}{*}{ Bacterium } & \multirow[t]{2}{*}{ Strain no.* } & \multirow[t]{2}{*}{ Place of isolation } & \multirow[t]{2}{*}{ Source } & \multirow[t]{2}{*}{ Reference $\dagger$} & \multicolumn{2}{|c|}{ Accession no. } \\
\hline & & & & & $\operatorname{gyr} \boldsymbol{B}_{\ddagger}^{+}$ & $16 S$ rDNA \\
\hline S. algae & ACAM 4733 & & & GenBank & & AF00669 \\
\hline S. algae & ATCC 51181 & Great Bay, NH, USA & Sediment & This study & AF005691 & $\mathrm{X} 81622$ \\
\hline S. algae & $\operatorname{ATCC} 51192^{\mathrm{T}}$ & Japan & Red algae & This study & AF005686 & AF005249 \\
\hline S. algae & BCM-8 & Chesapeake Bay, MD, USA & Water & This study & AF005687 & \\
\hline S. algae & IAM 14159 & Japan & Red algae & GenBank & & U91546 \\
\hline S. algae & SP-1 & & Clinical isolate & This study & AF005688 & \\
\hline S. algae & SP-5 & & Clinical isolate & This study & AF005689 & \\
\hline S. algae & SP-8 & & Clinical isolate & This study & AF005690 & \\
\hline S. algae & $\mathrm{T} \phi 8$ & Denmark, 1994 & Seawater & Fonnesbech-Vogel et al. (1997) & & U91547 \\
\hline S. algae & $14.80-\mathrm{A}$ & France, 1980 & Flamingo & Fonnesbech-Vogel et al. (1997) & & U91554 \\
\hline S. algae & $189-\mathrm{tr}$ & Italy & Fresh chicken breast & Fonnesbech-Vogel et al. (1997) & & U91554 \\
\hline S. algae & 43940 & Denmark, 1994 & Human blood & Fonnesbech-Vogel et al. (1997) & & U91545 \\
\hline S. algae & 68872 & Denmark, 1994 & Human ear infection & Fonnesbech-Vogel et al. (1997) & & U91548 \\
\hline S. amazonensis & ATCC $700329^{\mathrm{T}}$ & Amazon & Water & Venkateswaran et al. (1998) & AF005257 & AF005248 \\
\hline S. baltica & NCTC $10735^{\mathrm{T}}$ & Japan & Oil brine & Ziemke et al. (1998) & & AJ000214 \\
\hline S. baltica & OS 155 & Baltic Sea & Water & Ziemke et al. (1998) & & AJ000215 \\
\hline S. baltica & OS 195 & Baltic Sea & Water & Ziemke et al. (1998) & & AJ000216 \\
\hline S. baltica & F137 & Sweden, 1990 & Pike & Fonnesbech-Vogel et al. (1997) & & U91552 \\
\hline S. baltica & NCTC 10695 & Formerly Pseudomonas rubescens & Oil emulsion & GenBank & & U91553 \\
\hline S. benthica & ATCC 43991 & & & GenBank & & U91594 \\
\hline S. benthica & $\operatorname{ATCC} 43992^{\mathrm{T}}$ & & & This study & AF014949 & $\mathrm{X} 82131$ \\
\hline S. benthica & F1A & & & GenBank & & U91592 \\
\hline S. frigidimarina & $\mathrm{A} 173$ & Antarctica & & GenBank & & U85902 \\
\hline S. frigidimarina & ICO $10^{\mathrm{T}} ;$ ACAM $591^{\mathrm{T}}$ & Antarctica & & This study & AF014947 & U85906 \\
\hline S. frigidimarina & ICP1 & Antarctica & & GenBank & & U85903 \\
\hline S. frigidimarina & ICP4 & Antarctica & & GenBank & & U85905 \\
\hline S. frigidimarina & ICP12 & Antarctica & & GenBank & & U85904 \\
\hline S. frigidimarina & NCIMB 400 & & & GenBank & & Y13699 \\
\hline S. gelidimarina & ACAM $456^{\mathrm{T}}$ & Antaretica & & This study & AF014946 & U85907 \\
\hline S. hanedai & ATCC $33224^{\mathrm{T}}$ & Arctic & Sediment & This study & AF005693 & U91590 \\
\hline S. hanedai & CIP103207 & & & GenBank & & $\mathrm{X} 82132$ \\
\hline S. hanedai & $\mathrm{ICO} 50$ & Antarctica & & GenBank & & U85908 \\
\hline S. hanedai & 35256 & & & GenBank & & U91589 \\
\hline S. oneidensis & DLM-7 & Green Bay, Lake Michigan, WI, USA & Sediment & This study & AF005697 & \\
\hline S. oneidensis & ATCC $700550^{\mathrm{T}} ; \mathrm{MR}-1$ & Oneida Lake, NY, USA & Sediment & This study & AF005694 & AF005251 \\
\hline S. oneidensis & $\mathrm{MR}-4$ & Black Sea & Water column $5 \mathrm{~m}$ depth & This study & AF005695 & AF005252 \\
\hline S. oneidensis & MR-7 & Black Sea & Water column $60 \mathrm{~m}$ depth & This study & AF005696 & AF005253‡ \\
\hline S. oneidensis & MR-8 & & & This study & & AF005254 $\ddagger$ \\
\hline S. oneidensis & SP-3 & & Clinical isolate & This study & AF005698 & \\
\hline S. oneidensis & SP-7 & & Clinical isolate & This study & AF039060 & AF039054 \\
\hline S. oneidensis & SP-22 & & Clinical isolate & This study & AF039058 & AF039055 \\
\hline S. oneidensis & SP-32 & & Clinical isolate & This study & AF039059 & AF039056 \\
\hline 'S. pealeana' & ATCC $700345^{T}$ & & & This study & AF014945 & AF011335 \\
\hline 'S. pealeana' & ANG-SQ2 & & & This study & AF039061 & \\
\hline S. putrefaciens & ACAM 122 & Antarctica & & GenBank & & U39398 \\
\hline S. putrefaciens & ACAM 574 & Antarctica & & GenBank & & AF006670 \\
\hline S. putrefaciens & ATCC $8071^{\mathrm{T}}$ & England, 1931 & Butter & This study & AF005669 & U91550 \\
\hline S. putrefaciens & ATCC 8072 & England, 1931 & Butter & This study & AF005670 & Unpublished + \\
\hline S. putrefaciens & $\mathrm{BC}-1$ & Blue Clay, IN, USA & Karst stream water & This study & AF005684 & \\
\hline S. putrefaciens & $\mathrm{CE}-1$ & $\begin{array}{l}\text { Melt Pool, Near Cape Evans, Ross } \\
\text { Island, Antarctica }\end{array}$ & Water & This study & AF005676 & \\
\hline S. putrefaciens & CE-10 & $\begin{array}{l}\text { Melt Pool, Near Cape Evans, Ross } \\
\text { Island, Antarctica }\end{array}$ & Water & This study & AF005677 & \\
\hline S. putrefaciens & CG-1 & KinnicKinnick River, WI, USA & Water & This study & AF005671 & \\
\hline S. putrefaciens & CG-3 & KinnicKinnick River, WI, USA & Water & This study & AF005672 & \\
\hline S. putrefaciens & DLM-1 & Western Lake Michigan, WI, USA & Plankton & This study & AF005678 & \\
\hline S. putrefaciens & DLM-2 & Green Bay, Lake Michigan, WI, USA & Sediment & This study & AF005679 & \\
\hline S. putrefaciens & DLM-13 & Mid-Lake Michigan, WI, USA & Sediment & This study & AF005680 & \\
\hline S. putrefaciens & LMP-1 & $\begin{array}{l}\text { Chemocline, Lower Mystic Pond, MA, } \\
\text { USA }\end{array}$ & Water & This study & AF005673 & \\
\hline S. putrefaciens & LMP-9 & $\begin{array}{l}\text { Chemocline, Lower Mystic Pond, MA, } \\
\text { USA }\end{array}$ & Water & This study & AF005674 & \\
\hline S. putrefaciens & LW-1 & Lemonweir River, WI, USA & Water & This study & AF005683 & \\
\hline S. putrefaciens & NCIMB 12577 & Canada, $1983 ;$ strain 200 & Crude oil, Pembina oilfield & This study & AF014948 & U91557 \\
\hline S. putrefaciens & MR-30 & Green Bay, Lake Michigan, WI, USA & Sediment & This study & AF005675 & AF005255 \\
\hline S. putrefaciens & SP-10 & & Clinical isolate & This study & AF039057 & \\
\hline S. putrefaciens & WAB-1 & Wabash River, IN, USA & Water & This study & AF005685 & \\
\hline S. putrefaciens & $1 \mathrm{M}-1$ & One Mile River, WI, USA & Creek water & This study & AF005681 & \\
\hline S. putrefaciens & $7 \mathrm{M}-1$ & Seven Mile River, WI, USA & Creek water & This study & AF005682 & \\
\hline S. woodyi & ATCC $51908^{\mathrm{T}}$ & Persian Gulf & Water & This study & AF014944 & AF003548 \\
\hline Shewanella sp. & ATCC 8073 & England, 1931 & Butter & This study & Unpublished & Unpublished + \\
\hline Shewanella sp. & A6 & Denmark, 1986 & Whole gutted cod & Fonnesbech-Vogel et al. (1997) & & U91549 \\
\hline Shewanella sp. & ACAM 576 & Antarctica & & GenBank & & AF006671 \\
\hline Shewanella sp. & ACAM 577 & Antarctica & & GenBank & & AF006672 \\
\hline
\end{tabular}

* ACAM, Australian Collection of Antarctic Micro-organisms, Australia; ATCC, American Type Culture Collection, USA; IAM, Institute of Applied Microbiology, Japan; NCIMB, National Collection of Industrial and Marine Bacteria, UK; NCTC, National Collection of Type Cultures, UK. All other acronyms are strain numbers designated by individual researchers.

† Various data and cultures are either generated in this study or obtained from the mentioned bibliography, database or researcher. $\$$ Nucleotide sequence data generated in this study. 
nese and iron oxides (Myers \& Nealson, 1988), iron in clays (Kostka et al., 1996), uranium (Lovely \& Phillips, 1988), thiosulfate (Perry et al., 1993) and elemental sulfur (Perry et al., 1993; Moser \& Nealson, 1996). While long regarded as physiologically feasible, it was only in 1988 that the coupling of bacterial energy generation and growth to the reduction of iron and manganese oxides was demonstrated in Shewanella $\mathrm{sp}$. MR-1 (Myers \& Nealson, 1988; Nealson \& Saffarini, 1996). Strain MR-1, formerly identified as Shewanella putrefaciens, is of particular interest because its total genome is currently being sequenced by The Institute of Genomic Research (TIGR, Bethesda, MD, USA).

Despite the applied microbiological relevance and diversity of function embodied by this group, the phylogenetic breadth and organization of the shewanellae remains incompletely addressed (Farmer, 1992; Stenstrom \& Molin, 1990; Fonnesbech-Vogel et al., 1997). Introduced as Achromobacter putrefaciens in 1931 (Derby \& Hammer, 1931), the genus has undergone several name changes. In 1960, Shewan et al. (1960) reassigned Achromobacter putrefaciens to the genus Pseudomonas and, in 1977, Lee et al. (1977) further changed the genus designation to Alteromonas. The species Alteromonas putrefaciens remained the sole described member of the genus until the introduction of the bioluminescent Alteromonas hanedai in 1980 (Jensen et al., 1980). In 1985, MacDonell \& Colwell (1985) argued for the reclassification of these organisms into a new genus on the basis of 5S rRNA sequence data and proposed the name Shewanella.

The deep sea isolate, Shewanella benthica (MacDonell $\&$ Colwell, 1985), the marine non- $\mathrm{H}_{2} \mathrm{~S}$-producing bacterium, Shewanella colwelliana (Weiner et al., 1988; Coyne et al., 1989) and the clinically important Shewanella algae (Simidu et al., 1990; Nozue et al., 1992; species name changed from Shewanella alga to Shewanella algae by Trüper \& de' Clari, 1997) were included in Shewanella genus. To this day, S. putrefaciens remains, almost by default, the phenotypic resting place for a growing conglomerate of nonfermentative, mostly $\mathrm{H}_{2} \mathrm{~S}$-producing aerobes loosely associated with aquatic habitats. The phenotypic boundaries of and within this group remain ill-defined for lack of a diagnostically informative pattern of phenotypic characteristics. However, with the recent improvements in the applicability of molecular approaches for microbial phylogeny, efforts are under way to clarify the phylogenetic organization of this genus. One result has been the reassessment of the distinctions between $S$. putrefaciens and $S$. algae (Fonnesbech-Vogel et al., 1997). Likewise, Ziemke et al. (1998) showed that members of Owen's genomic group II (Owen et al., 1978) of S. putrefaciens are phenotypically, genotypically and phylogenetically distinct enough from the rest of the $S$. putrefaciens members to be classified as a new species, Shewanella baltica. Also, a number of novel species have been recently introduced, including: the luminous species, Shewanella woodyi (Makemson et al., 1997); two marine Antarctic taxa, Shewanella gelidimarina and Shewanella frigidimarina (Bowman et al., 1997); Shewanella amazonensis (Venkateswaran et al., 1998b); and a possibly symbiotic representative, 'Shewanella pealeana' (Leonardo et al., 1999).

Whereas the gene sequence of the small subunit of the 16S rRNA molecule is accepted for the definition of phylogenetic relationships between organisms (Woese, 1987), this molecule, at times, lacks the specificity required for the differentiation of close relatives (Venkateswaran et al., 1998a; Fox et al., 1992). To circumvent this limitation, the more rapidly evolving gyr B gene, (encoding the B subunit of the DNA gyrase, topoisomerase type II) (Edgell \& Doolittle, 1997), has been employed as a high-resolution molecular identification marker for distinguishing strains of Vibrio (Venkateswaran et al., 1998a), Acinetobacter, Pseudomonas, (Yamamoto \& Harayama, 1995, 1996) and now Shewanella.

In this work, a reorganization of the genus Shewanella is proposed using a combination of two types of nucleotide sequence data, DNA-DNA reassociation, molecular probing, fatty acid and quinone profiling, and classical physiological testing. To assemble this polyphasic data set, the published works of other authors have been used, a variety of unpublished contributions from co-authors has been assembled and a large volume of data for established strains and new isolates collected expressly for this study has been generated. A new species, Shewanella oneidensis sp. nov. (type strain ATCC $700550^{\mathrm{T}}$; formerly known as Shewanella sp. MR-1 or Shewanella putrefaciens MR$1)$, is also described.

\section{METHODS}

Bacterial strains and growth conditions. Micro-organisms included in this study were isolated from various environmental sources, purchased from culture collections or were the gifts of others (Table 1). The isolation of Shewanella-like organisms was carried out by employing a variation of a previously described sulfur-agar-plate method (Moser \& Nealson, 1996). Water or sediment slurry samples were collected in sterile containers and stored at $4^{\circ} \mathrm{C}$ until bacteriological examinations were carried out. Typically, $100 \mu \mathrm{l}$ of a given sample was spread with a flamed, glass rod over the surface of plates of half-strength LB agar (Miller, 1972) supplemented with sulfur and lactate at 40 and $30 \mathrm{mM}$, respectively (LB/S ${ }^{0} /$ Lac; Moser \& Nealson, 1996). Plates were first incubated under aerobic conditions at room temperature (ca. $25^{\circ} \mathrm{C}$ ) for several days to obtain a collection of aerobic isolates. Colonies obtained in this manner were then screened for sulfur reduction after transfer of the plates into an anaerobic chamber (Coy Laboratory Products) maintained at $2 \% \mathrm{H}_{2}$, with the remainder being $\mathrm{N}_{2}$. Salmoncoloured colonies displaying cleared zones characteristic of sulfur-reducing bacteria (Moser \& Nealson, 1996) were regarded as potential Shewanella candidates and subcultured by several rounds of streaking for isolation onto fresh plates.

Pure cultures obtained from other sources (Table 1) were likewise screened for sulfur reduction by streaking for isolation onto $\mathrm{LB} / \mathrm{S}^{0} / \mathrm{Lac}$ medium and following the same 
two-step incubation procedure. For routine cultivation, cells were grown aerobically either in liquid with agitation or on LB agar media at $30^{\circ} \mathrm{C}$ without additions. ' $S$. pealeana' ATCC $700345^{\mathrm{T}}$ was originally isolated on $\mathrm{LB} / \mathrm{S}^{0} / \mathrm{Lac}$ and subsequently grown on a defined medium called M1N (Leonardo et al., 1999), an adaptation of M1 minimal medium (Myers \& Nealson, 1988), supplemented with $0.5 \mathrm{M}$ $\mathrm{NaCl}$ or on Marine agar (Difco).

Phenotypic characterization. Routine biochemical tests were carried out according to established procedures (Venkateswaran et al., 1989; West \& Colwell, 1984; Baumann et al., 1984). The ability to grow at an $\mathrm{NaCl}$ concentration of $1-10 \%$ was determined in $T_{1} N_{1}$ liquid medium (Venkateswaran et al., 1989), and the ability to grow without $\mathrm{NaCl}$ was determined in $1 \%$ sterile tryptone water. Sugars and amino acids were tested on LB broth at a concentration of $1 \%$ as described elsewhere (West \& Colwell, 1984). Haemolytic activity was recorded on Trypticase soy agar supplemented with $5 \%$ defibrinated sheep blood. Additional phenotypic characteristics were determined by the BIOLOG microbial identification system. For the determination of cell shape and size and the detection of flagella, cells were negatively stained with osmium chloride according to the methods of Cole \& Popkin (1981) and observed with a Hitachi transmission electron microscope (H-600).

Iron reduction. Bacterial colonies were streaked onto LM medium $(0.02 \%$ yeast extract, $0.01 \%$ peptone, $0.6 \% \mathrm{NaCl}$, $10 \mathrm{mM}$ sodium bicarbonate, $10 \mathrm{mM}$ HEPES) supplemented with carbon substrates as appropriate $(5 \mathrm{mM}$ lactate, $5 \mathrm{mM}$ succinate, $5 \mathrm{mM}$ glycerol, $1 \mathrm{mM}$ acetate), $50 \mathrm{mM}$ ferric citrate, $5 \mathrm{mM}$ sodium molybdate and the colour reagent ferrozine [3-(2-pyridyl)-5,6-bis(4-phenylsulfonic acid)-1,2,4 triazine, $\mathrm{pH} 7 \cdot 2$ ]. Plates were incubated anaerobically at room temperature until colonies appeared (after ca. $7 \mathrm{~d}$ ). Colonies displaying cleared zones were scored as positive for iron reduction. Shewanella sp. MR-1 and Escherichia coli ATCC 25922 were included as positive and negative controls, respectively.

Fatty acid analysis. Cells were cultivated overnight in liquid $\mathrm{LB}$ medium at $30^{\circ} \mathrm{C}$ with vigorous shaking. Cellular fatty acids were extracted from lyophilized cells, methylated and analysed by GC (Ringelberg et al., 1994). Fatty acid methyl esters (FAME) were analysed on a cross-linked $5 \%$ phenyl silicone capillary column $(0.2 \mathrm{~mm}$ i.d.; $25 \mathrm{~m}$ long; Hewlett Packard) with a HP 5890A gas chromatograph. The column was kept at an initial temperature of $80^{\circ} \mathrm{C}$ for 2 min and the temperature was programmed to increase from 80 to $150^{\circ} \mathrm{C}$ at $10^{\circ} \mathrm{C} \mathrm{min}-1$, then to $282^{\circ} \mathrm{C}$ at $3^{\circ} \mathrm{C} \mathrm{min}-1$ and finally held at $282^{\circ} \mathrm{C}$ for $5 \mathrm{~min}$. The temperature of the injector was maintained at $250^{\circ} \mathrm{C}$ and the detector was kept at $290^{\circ} \mathrm{C}$. The FAME peaks were identified by retention time comparisons against authentic standards and quantified by integration of peak areas. In addition, FAME peaks were also identified by MS (electron impact at $70 \mathrm{eV}$ ) including verification of double-bond position via dimethyl disulfide derivatization (Ringelberg et al., 1994).

Quinone analysis. Fully grown overnight cultures were diluted 100 -fold into $25 \mathrm{ml}$ fresh LB and incubated at $30^{\circ} \mathrm{C}$ with vigorous shaking until $\mathrm{OD}_{600}$ of 1 was reached. Aliquots from this culture were spread-plated on LB agar and incubated at $30^{\circ} \mathrm{C}$ for $6 \mathrm{~h}$. Cells were harvested by scraping, pooled, centrifuged and frozen prior to lyophilization (Lies et al., 1996). Quinones were twice extracted with chloroform $/$ methanol $(2: 1, \mathrm{v} / \mathrm{v})$ from lyophilized ground cells. After centrifugation, the solvent phase was collected, evap- orated to dryness and then resuspended in a known volume of acetone to normalize with respect to original biomass. Samples were quantified by comparison to a standard curve prepared with two known quinones (MK-4 and Q-10; Sigma). Quinones were separated by HPLC and individually identified by MS (Nishijima et al., 1997). The relative molar ratios of quinone homologues were determined by reference to standard mixtures containing known amounts of MK-4 and Q-10 compounds.

\section{Molecular characterization}

Purified genomic DNA (Johnson, 1981) from liquid-grown cultures was used as the template for PCR amplification unless otherwise specified. PCR assays were performed in a DNA Thermal Cycler (Perkin-Elmer).

(i) DNA isolation and characterization. The DNA was isolated by chromatography on hydroxyapatite by the procedure of Cashion et al. (1977) for G+C (mol \%) and DNA-DNA hybridization analyses. The $\mathrm{G}+\mathrm{C}$ content of the DNA was determined by HPLC as described by Mesbah et al. (1989). DNA-DNA hybridization was carried out according to De Ley et al. (1970) with modifications as described by $\mathrm{Huß}$ et al. (1983) and Escara \& Hutton (1980) using a Gilford System 2600 spectrophotometer equipped with a Gilford 2527-R thermoprogrammer and plotter. Renaturation rates were computed by the program TRANSFER.BAS (Jahnke, 1992). Strains included in the DNA-DNA hybridization experiments were: $S$. algae ATCC $51192^{\mathrm{T}}, S$. amazonensis ATCC $700329^{\mathrm{T}}, S$. hanedai DSM $6066^{\mathrm{T}}, S$. benthica DSM $8812^{\mathrm{T}}$, Shewanella oneidensis sp. nov. ATCC $700550^{\mathrm{T}}$, ' $S$. pealeana' ATCC $700345^{\mathrm{T}}, S$. putrefaciens ATCC $8071^{\mathrm{T}}$ and S. woodyi ATCC $51908^{\mathrm{T}}$.

(ii) 165 rDNA. Universal primers (Bact 11 and 1492) were used to amplify the $1.4 \mathrm{~kb}$ PCR fragment according to the protocols established by Ruimy et al. (1994). Amplicons thus generated were purified and sequenced as described below.

(iii) gyrB gene. Primers (UP-1 and UP-2r) within the known DNA sequence (Yamamoto \& Harayama, 1995) were added to the PCR mixture at a concentration of $1 \mu \mathrm{M}$ and the solution was subjected to 30 cycles of PCR (Venkateswaran et al., 1998a). Amplified gyrB fragments $(1 \cdot 2 \mathrm{~kb})$ from $S$. putrefaciens ATCC $8071^{\mathrm{T}}$ and $S$. hanedai ATCC $33224^{\mathrm{T}}$ were cloned in pGEM-ZF $(+)$ (Promega) by conventional recombinant methods (Sambrook et al., 1989). Expansion of the probes was carried out as documented previously (Sambrook et al., 1989). After the ligation of PCR fragments into the vector, $E$. coli cells were transformed with the ligation mixture by the calcium chloride method and transformants were cultured under conditions which promote growth. Plasmids were recovered from transformants by the alkaline lysis method. The purified intact plasmids were then utilized as probes. DNA sequences were determined for both strands by extension from vector-specific [T 7 and SP- 6 primers from pGEM-ZF $(+)$ ] priming sites and by primer walking. For all of the other strains, the cloning step was eliminated and PCR-amplified $1.2 \mathrm{~kb}$ gyr $B$ products were sequenced directly following purification on Qiagen columns.

(iv) Sequencing. The identity of a given PCR product was verified by sequencing using the dideoxy chain-termination method with the Sequenase DNA Sequencing kit (United States Biochemical) and an ABI 373A automatic sequencer as recommended by the manufacturer (Perkin-Elmer Applied Biosystems). 
(v) Molecular identification of S. putrefaciens. By comparing the gyrB sequences of four Shewanella species (S. putrefaciens ATCC $8071^{\mathrm{T}}, S$. algae ATCC $51192^{\mathrm{T}}, S$. hanedai ATCC $33224^{\mathrm{T}}$ and $S$. benthica ATCC 43992 ${ }^{\mathrm{T}}$ ) a suitable PCR primer set (SP-1, 5' TTC GTC GAT TAT TTG AAC AGT $3^{\prime}$ and SP-2r, 5' TTT TCC AGC AGA TAA TCG TTC 3') was designed from within the $g y r B$ sequence of type strain ATCC $8071^{\mathrm{T}}$ to specifically identify $S$. putrefaciens. The generation of a predicted $422 \mathrm{bp}$ amplicon using these primers was inferred to indicate the presence of $S$. putrefaciens template DNA in a given sample. Amplification was performed using 30 PCR cycles, each consisting of $1 \mathrm{~min}$ at $94^{\circ} \mathrm{C}, 1.5 \mathrm{~min}$ at $58^{\circ} \mathrm{C}, 2.5 \mathrm{~min}$ at $72^{\circ} \mathrm{C}$ and a final extension step at $72{ }^{\circ} \mathrm{C}$ for $7 \mathrm{~min}$. The $422 \mathrm{bp}$ amplicon was analysed by agarose gel electrophoresis (Venkateswaran et al., 1998a). Suitable molecular size markers were included in each gel.

Phylogenetic analysis and sequence alignment. The phylogenetic relationships of organisms covered in this study were determined by comparison of individual 16S rDNA sequences with the approximately 10700 sequences that already exist in the ribosomal database for other members of the $\gamma$-subclass of the Proteobacteria. gyr $B$ sequences were compared with ca. 300 other gyr $B$ sequences in the database maintained by our laboratory and the Marine Biotechnology Institute, Kamaishi, Japan. Evolutionary trees were constructed with the PAUP (Swofford, 1990), PHYLIP (Felsenstein, 1990) and ARB program packages (Strunk \& Ludwig, 1995). Nucleotide sequence accession numbers are given in Table 1.

\section{RESULTS}

Twelve species of the genus Shewanella have been reported or proposed as of this writing (based on $16 \mathrm{~S}$ rDNA data in the GenBank database). Although the Committee on Reconciliation of Approaches to Bacterial Systematics validated $S$. colwelliana as a recognized Shewanella species (Weiner et al., 1988), this species has not been considered because its 16S rRNA sequence has never been reported.

\section{Morphological characteristics}

All Shewanella strains examined were Gram-negative, rod-shaped and non-spore-forming (Table 2). Cells were $2-3 \mu \mathrm{m}$ in length and $0.4-0.7 \mu \mathrm{m}$ in diameter and were motile by means of a single unsheathed polar flagella. Cells grown on suitable agar media produced young colonies which were circular, $1-4 \mathrm{~mm}$ in diameter, smooth, convex and with regular edges. $S$. algae, S. amazonensis, S. frigidimarina, S. gelidimarina, $S$. oneidensis and $S$. putrefaciens showed pinkish coloration on LB agar whereas $S$. benthica, $S$. hanedai, ' $S$. pealeana' and $S$. woodyi exhibited less intensively coloured colonies on marine agar.

\section{Physiological properties}

$S$. benthica grew optimally at ca. $4^{\circ} \mathrm{C}, S$. hanedai at $15-25^{\circ} \mathrm{C}, S$. gelidimarina at $15^{\circ} \mathrm{C}$ and the other species at $25-35^{\circ} \mathrm{C}$. S. algae, S. amazonensis and some of the strains of $S$. oneidensis exhibited growth at $40^{\circ} \mathrm{C}$. In this report, a halotolerant strain is defined as one that grows optimally in media containing $0 \cdot 0-0 \cdot 3 \mathrm{M} \mathrm{NaCl}$
(Gilmour, 1990). Although the halotolerant strains grew even in the absence of $\mathrm{NaCl}$, growth was accelerated in the presence of $0.2 \mathrm{M} \mathrm{NaCl}$. Of the species considered here, $S$. algae, $S$. amazonensis, $S$. frigidimarina, $S$. oneidensis and $S$. putrefaciens fit this criterion. Alternatively, the halophiles [strains that grow optimally in media containing $0 \cdot 2-2 \cdot 0 \mathrm{M} \mathrm{NaCl}$ (Gilmour, 1990)], S. benthica, S. hanedai, S. gelidimarina, 'S. pealeana' and $S$. woodyi grew on marine agar or any of a number of media supplemented with sufficient salts.

All strains were positive for cytochrome oxidase and catalase and negative for the production of amylase, alginase, arginine dihydrolase and lysine as well as ornithine decarboxylases. Gelatinase was produced by $S$. algae, $S$. amazonensis, $S$. hanedai, $S$. frigidimarina, $S$. gelidimarina and $S$. oneidensis and lipase was produced by $S$. hanedai and ' $S$. pealeana'. Indole and acetoin were not produced by any strains. Visible bioluminescence was observed only in $S$. hanedai and S. woodyi.

The inability to ferment glucose has traditionally been employed as a defining characteristic of the shewanellae. However, Bowman et al. (1997) have reported glucose fermentation in $S$. benthica and $S$. frigidimarina.

\section{Anaerobic electron acceptor reduction}

All known shewanellae reduced trimethylamine $N$ oxide (TMAO) and the majority produced $\mathrm{H}_{2} \mathrm{~S}$ from thiosulfate. All Shewanella strains reduced nitrate to nitrite. Elemental sulfur reduction, as determined by the agar-plate-clearing assay (Moser \& Nealson, 1996) was seen in $S$. algae, $S$. amazonensis, $S$. oneidensis, ' $S$. pealeana' and $S$. putrefaciens, whereas $S$. hanedai and $S$. woodyi were negative. The same pattern was noted for iron reduction. Key diagnostic traits for the differentiation of all known 11 shewanellae are given in Table 2.

\section{Phenotypic differentiation of Shewanella into its species}

Shewanella strains are defined as being Gram-negative, oxidase- and catalase-positive and capable of reducing TMAO; the majority produce $\mathrm{H}_{2} \mathrm{~S}$ from thiosulfate. Glucose fermentation readily distinguishes $S$. frigidimarina and $S$. benthica from the remaining eight known shewanellae (Bowman et al., 1997). Whereas the dissimilatory reduction of iron differentiates these shewanellae from other carbohydrate-fermenting organisms, the absence of growth at $20^{\circ} \mathrm{C}$ distinguishes $S$. benthica from $S$. frigidimarina. Among the eight remaining shewanellae, the halophiles, $S$. gelidimarina, $S$. hanedai, ' $S$. pealeana' and $S$. woodyi and the halotolerant strains, $S$. algae, $S$. amazonensis, $S$. oneidensis and $S$. putrefaciens form distinct clusters. The halophiles can be further separated on the basis of bioluminescence with the $S$. gelidimarina/' $S$. pealeana' group being non-luminous. The lipase test can be 
Table 2. Phenotypic characterization of various Shewanella species

1, S. algae $(n=4) ; 2$, S. amazonensis ATCC 700329 $; 3$, S. baltica NCTC $10735^{\mathrm{T}}$ [data reproduced from Ziemke et al., (1998)]; 4, S. benthica ATCC $43922^{\mathrm{T}}$ [data reproduced from MacDonell \& Colwell (1985) and Bowman et al. (1997)]; 5, S. hanedai ATCC $33224^{\mathrm{T}}$ [data reproduced from Jensen et al. (1980)]; 6, S. frigidimarina ACAM 591 ${ }^{\mathrm{T}}$ [data reproduced from Bowman et al. (1997)]; 7, S. gelidimarina ACAM 456 ${ }^{\mathrm{T}}$ [data reproduced from Bowman et al. (1997)]; 8, S. oneidensis $(n=5)$; 9, ' $S$. pealeana' ATCC $700345^{\mathrm{T}}$ [data reproduced from Leonardo et al. (1999)]; 10, S. putrefaciens $(n=10) ; 11, S$. woodyi ATCC $51908^{\mathrm{T}}$ [data reproduced from Makemson et al. (1997)]. All strains showed the presence of a single polar flagellum, growth in the presence of $3 \% \mathrm{NaCl}$, oxidase and catalase production. All strains were Gram-negative and did not produce alginase, arginine dihydrolase, lysine or ornithine decarboxylase. None of the strains produced indole or acetoin. Apart from the values given in the first five rows, numbers denote the percentage of strains giving a positive reaction.

\begin{tabular}{|c|c|c|c|c|c|c|c|c|c|c|c|}
\hline Character & 1 & 2 & 3 & 4 & 5 & 6 & 7 & 8 & 9 & 10 & 11 \\
\hline Cell shape & Straight rod & Straight rod & Straight rod & $\begin{array}{c}\text { Curved } \\
\text { rod }\end{array}$ & Straight rod & $\begin{array}{l}\text { Straight or } \\
\text { curved rod }\end{array}$ & $\begin{array}{l}\text { Straight or } \\
\text { curved rod }\end{array}$ & Straight rod & Straight rod & Straight rod & Straight rod \\
\hline Luminescence & - & - & - & - & + & - & - & - & - & - & + \\
\hline DNA G + C (mol \%) & $52-55$ & 52 & 46 & 47 & 45 & $40-43$ & 48 & 45 & 45 & $43-47$ & 39 \\
\hline Optimal growth temp. $\left({ }^{\circ} \mathrm{C}\right)$ & $25-35$ & $25-35$ & & $4-15$ & $\leqslant 25$ & $20-22$ & $15-17$ & $25-35$ & $25-30$ & $25-35$ & 25 \\
\hline Optimal pH for growth & $7-8$ & $7-8$ & & & & & & $7-8$ & $7-8$ & $7-8$ & $7-8$ \\
\hline \multicolumn{12}{|l|}{ Growth at: } \\
\hline $4^{\circ} \mathrm{C}$ in $24 \mathrm{~h}$ & 0 & + & + & + & + & + & + & 20 & - & 100 & + \\
\hline $35^{\circ} \mathrm{C}$ & 100 & + & & - & - & - & - & 100 & - & $80^{*}$ & - \\
\hline $40^{\circ} \mathrm{C}$ & 100 & + & - & - & - & & & 60 & - & 0 & - \\
\hline $\mathrm{NO}_{3}$ to $\mathrm{NO}_{2}$ & 100 & + & + & + & + & + & + & 80 & + & 100 & + \\
\hline \multicolumn{11}{|l|}{ Production of: } & - \\
\hline Amylase & 0 & - & & - & + & - & - & 0 & - & 0 & + \\
\hline Gelatinase & 50 & + & & + & + & + & + & 100 & - & 0 & + \\
\hline Lipase & 0 & - & + & - & + & + & + & 0 & + & 0 & - \\
\hline Chitinase & & & & + & + & - & + & & & & - \\
\hline Haemolysis & 75 & + & & & & & & 0 & - & 0 & \\
\hline $\begin{array}{l}\mathrm{H}_{2} \mathrm{~S} \text { production from } \\
\mathrm{S}_{2} \mathrm{O}_{3}^{2-}\end{array}$ & 100 & + & + & + & - & + & + & 100 & + & 100 & - \\
\hline \multicolumn{12}{|l|}{ Growth in $\mathrm{NaCl}(\%)$ : } \\
\hline 0 & 100 & + & & - & - & + & - & 100 & - & 100 & - \\
\hline 6 & 100 & - & & - & - & + & + & 40 & - & 100 & - \\
\hline 10 & 100 & - & & - & - & - & - & 0 & - & 0 & - \\
\hline \multicolumn{12}{|l|}{ Utilization of: } \\
\hline D-Galactose & 75 & + & & & + & - & - & 80 & + & 100 & + \\
\hline D-Fructose & 0 & - & & & & - & - & 0 & - & 0 & \\
\hline Sucrose & 0 & - & + & & - & + & - & 0 & + & 40 & - \\
\hline Maitose & 25 & - & + & & & + & - & 0 & $\begin{array}{l}T \\
+\end{array}$ & 60 & \\
\hline Lactose & 0 & - & & & & & & 0 & - & 30 & \\
\hline Succinate & 50 & + & & & - & + & - & 100 & - & 60 & + \\
\hline Fumarate & 75 & + & & & & + & - & 80 & - & 60 & \\
\hline Citrate & 0 & - & + & & - & & & 0 & - & 0 & - \\
\hline D-Mannitol & 0 & - & & & & + & - & 0 & - & 0 & \\
\hline Glycerol & 0 & - & & & - & & & 0 & - & 0 & - \\
\hline D-Sorbitol & 0 & - & & & & & & 0 & - & 0 & \\
\hline DL-Malate & 0 & - & + & & & & & 0 & - & 0 & \\
\hline DL-Lactate & 100 & + & & & & & & 100 & - & 60 & \\
\hline \multicolumn{12}{|l|}{ Reduction of: $\dagger$} \\
\hline Iron oxide & 100 & + & + & + & - & + & + & 100 & + & 100 & - \\
\hline Manganese oxide & 100 & + & & + & - & & & 100 & + & 100 & - \\
\hline
\end{tabular}

* One strain showed a positive reaction after $48 \mathrm{~h}$ incubation.

$\uparrow$ Most of the strains were examined in this study.

employed to discriminate $S$. hanedai (positive) from $S$. woodyi (negative). The gelatin liquefaction test differentiates $S$. gelidimarina (positive) from ' $S$. pealeana' (negative). The halotolerant strains can be divided on the basis of gelatin liquefaction. In this regard, $S$. putrefaciens can be separated from the remainder by virtue of being gelatinase-negative. S. oneidensis can be distinguished from $S$. algae and $S$. amazonensis by its inability to haemolyse sheep blood. Finally, $S$. amazonensis can be differentiated from $S$. algae by growth at $4{ }^{\circ} \mathrm{C}$.

\section{Fatty acid analysis}

The FAME compositions of various Shewanella species are shown in Table 3. The FAME profiles display only those fatty acids comprising $\geqslant 0 \cdot 1 \%$ of the total. The elimination of minor fatty acids from consideration had no effect on any of the relationships described here. All of the values presented here were recalculated to show the relative abundance of the various fatty acids.

Straight-chain saturated FAME (20-41\%), terminally 
Table 3. Fatty acid composition (\%) of various Shewanella species

1, S. algae ATCC 51192 ; 2, S. amazonensis ATCC 700329" ; 3, S. benthica $(n=2)$ [data reproduced from Bowman et al. $(1997)$ ]; 4, $S$. frigidimarina $(n=8)$ [data reproduced from Bowman et al. (1997)]; 5, $S$. hanedai $(n=2)$ [data reproduced from Bowman et al. $(1997)] ; 6, S$. gelidimarina $(n=2)$ [data reproduced from Bowman et al. $(1997)$ ]; 7, S. oneidensis ATCC 700550 $; 8$, ' $S$. pealeana' ATCC $700345^{\mathrm{T}} ; 9, S$. putrefaciens ATCC $8071^{\mathrm{T}} ; 10, S$. woodyi $(n=2)$ [data reproduced from Makemson et al. (1997)]. Both $S$. frigidimarina and $S$. gelidimarina produce eicosapentaenoic acid, 20:5 23 .

\begin{tabular}{|c|c|c|c|c|c|c|c|c|c|c|}
\hline Fatty acid & 1 & 2 & 3 & 4 & 5 & 6 & 7 & 8 & 9 & 10 \\
\hline \multicolumn{11}{|c|}{ Straight chain saturated fatty acids: } \\
\hline $14: 0$ & $1 \cdot 3$ & $1 \cdot 4$ & $14 \cdot 3$ & $3 \cdot 7$ & $11 \cdot 5$ & $5 \cdot 1$ & $2 \cdot 6$ & $6 \cdot 1$ & $2 \cdot 3$ & $6 \cdot 7$ \\
\hline $15: 0$ & $6 \cdot 5$ & $9 \cdot 2$ & $0 \cdot 8$ & $2 \cdot 5$ & $4 \cdot 2$ & $5 \cdot 1$ & $4 \cdot 7$ & $2 \cdot 8$ & $3 \cdot 2$ & $5 \cdot 2$ \\
\hline $16: 0$ & $16 \cdot 8$ & $6 \cdot 1$ & $13 \cdot 8$ & $11 \cdot 8$ & $17 \cdot 6$ & $10 \cdot 9$ & $14 \cdot 8$ & $20 \cdot 3$ & $19 \cdot 1$ & $27 \cdot 5$ \\
\hline $17: 0$ & $4 \cdot 1$ & $3 \cdot 9$ & $5 \cdot 4$ & $1 \cdot 2$ & $1 \cdot 0$ & 0.6 & $2 \cdot 8$ & $1 \cdot 6$ & $1 \cdot 5$ & $1 \cdot 6$ \\
\hline $13: 0$-iso & $0 \cdot 5$ & $4 \cdot 7$ & $7 \cdot 3$ & $6 \cdot 3$ & $8 \cdot 3$ & $13 \cdot 1$ & $2 \cdot 5$ & $15 \cdot 1$ & $2 \cdot 5$ & $12 \cdot 4$ \\
\hline $14: 0$-iso & $1 \cdot 4$ & $1 \cdot 5$ & $1 \cdot 1$ & 0.6 & $0 \cdot 3$ & $0 \cdot 4$ & $2 \cdot 3$ & $1 \cdot 2$ & 0.3 & $0 \cdot 3$ \\
\hline $15: 0$-iso & $27 \cdot 4$ & $26 \cdot 7$ & $6 \cdot 6$ & $9 \cdot 0$ & $10 \cdot 4$ & $12 \cdot 3$ & $25 \cdot 4$ & $17 \cdot 5$ & $21 \cdot 1$ & $20 \cdot 1$ \\
\hline $16: 0$-iso & 0.5 & $1 \cdot 4$ & & & & & 1.4 & & $0 \cdot 1$ & \\
\hline $17: 0$-iso & $1 \cdot 4$ & 1.8 & 1.0 & $0 \cdot 3$ & $2 \cdot 1$ & $0 \cdot 3$ & $1 \cdot 7$ & $1 \cdot 1$ & 1.7 & $1 \cdot 4$ \\
\hline $17: 1 \omega 6 c$ & 0.9 & $2 \cdot 4$ & 0.7 & & & $1 \cdot 1$ & $1 \cdot 5$ & $1 \cdot 0$ & 0.9 & \\
\hline $17: 1 \omega 8 c$ & $10 \cdot 9$ & $23 \cdot 4$ & $5 \cdot 1$ & $3 \cdot 0$ & $1 \cdot 3$ & $3 \cdot 8$ & $8 \cdot 0$ & $3 \cdot 2$ & 6.7 & $2 \cdot 3$ \\
\hline $18: 1 \omega 7 c$ & $5 \cdot 2$ & $4 \cdot 5$ & $1 \cdot 1$ & $5 \cdot 3$ & $3 \cdot 8$ & $5 \cdot 8$ & $5 \cdot 7$ & $3 \cdot 2$ & $6 \cdot 0$ & $1 \cdot 2$ \\
\hline $18: 1 \omega 9 c$ & $4 \cdot 9$ & $1 \cdot 4$ & $0 \cdot 1$ & $1 \cdot 7$ & 0.6 & 0.7 & $2 \cdot 9$ & $2 \cdot 6$ & $3 \cdot 8$ & \\
\hline
\end{tabular}

branched saturated FAME (16-36\%) and monounsaturated FAME (25-65\%) were the major lipid classes detected. $S$. benthica, $S$. frigidimarina, $S$. hanedai and $S$. putrefaciens were high in terms of monounsaturates followed by straight-chain saturates and terminally branched saturates. As seen in the above group, $S$. algae, $S$. amazonensis, $S$. gelidimarina and $S$. oneidensis produced large amounts of monounsaturates but terminally branched saturates were more abundant than straight-chain saturates. All three groups of FAME were equally evident in ' $S$. pealeana' whereas $S$. woodyi synthesized high amounts of straight-chain saturates followed by terminally branched saturates and monounsaturates.

Palmitoleic acid $(16: 1 \omega 7 c)$ was the most abundant monounsaturate found in all Shewanella species, except for S. amazonensis, in which 17:1 $108 c$ was more abundant. Pentadecanoic acid (15:0) was the most abundant straight-chain saturated FAME in $S$. amazonensis, as compared to palmitic acid (16:0) which was most abundant in most of the other species. $S$. benthica and $S$. hanedai, however, produced proportionately more 14:0 than 16:0. Among terminally branched FAME, iso-pentadecanoic acid was the most abundant in all Shewanella species. However, 13:0-iso was also produced in considerable amounts in $S$. benthica, S. frigidimarina, S. hanedai, S. gelidimarina, ' $S$. pealeana' and $S$. woodyi.

\section{Quinone analysis}

The isoprenoid quinone composition for the type strains of three of the Shewanella species is given in Table 4. Under aerobic growth conditions, ubiquinones (predominantly Q-7 and Q-8) were present at much higher concentrations than menaquinones (predominantly MK-7). S. oneidensis $700550^{\mathrm{T}}$ and $S$. putrefaciens ATCC $8071^{\mathrm{T}}$ exhibited very similar overall quinone compositions, whereas $S$. hanedai ATCC $33224^{\mathrm{T}}$ had relatively lower menaquinone (MK-7) levels and lacked MMK-7. Although the type strain of $S$. algae has not been tested, strains of ' $S$. putrefaciens' group IV (Owen et al., 1978) (now classified as $S$. algae) have been examined (Akagawa-Matsushita $e t$ al., 1992; Moule \& Wilkinson, 1987). The quinone compositions of group IV strains strongly resemble those of $S$. oneidensis and $S$. putrefaciens.

\section{Molecular phylogenetic analysis}

(i) $16 \mathrm{~S}$ rDNA sequence analysis. The $1.4 \mathrm{~kb}$ nucleotide sequences of the 16S rDNA covering base positions 11-1492 (E. coli numbering), were determined for the 
Table 4. Isoprenoid quinone composition (\%) of Shewanella species

\begin{tabular}{|c|c|c|c|c|c|c|c|c|}
\hline Strain & Q-6 & Q-7 & Q-8 & Q-9 & MK-7 & MK-8 & MMK-7 & Reference \\
\hline S. oneidensis ATCC $700550^{\mathrm{T}}$ & 2 & 25 & 27 & & 41 & & 6 & This work \\
\hline S. putrefaciens ATCC $8071^{\mathrm{T}}$ & 2 & 36 & 42 & 1 & 11 & & 7 & This work \\
\hline S. putrefaciens ATCC $8071^{\mathrm{T}}$ & 1 & 11 & 34 & & 44 & 2 & 6 & $\begin{array}{l}\text { Akagawa-Matsushita et al. } \\
\text { (1992) }\end{array}$ \\
\hline S. hanedai ATCC $33224^{\mathrm{T}}$ & & 35 & 58 & 1 & 6 & & & $\begin{array}{l}\text { Akagawa-Matsushita et al. } \\
\text { (1992) }\end{array}$ \\
\hline
\end{tabular}

Table 5. $16 \mathrm{~S}$ rDNA nucleotide sequence similarities (\%) among known Shewanella species

Shewanella species: 1 , S. algae ATCC $51192^{\mathrm{T}} ; 2$, S. amazonensis ATCC 700329 $;$ 3, S. baltica NCTC 10735 $;$, 4, S. benthica

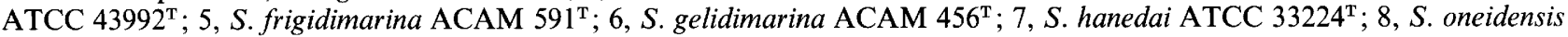
ATCC $700550^{\mathrm{T}} ; 9$, 'S pealeana' ATCC $700345^{\mathrm{T}} ; 10, S$. putrefaciens ATCC $8071^{\mathrm{T}} ; 11$, S. woodyi ATCC $51908^{\mathrm{T}}$.

\begin{tabular}{|lcccccccccc|}
\hline Species & $\mathbf{1}$ & $\mathbf{2}$ & $\mathbf{3}$ & $\mathbf{4}$ & $\mathbf{5}$ & $\mathbf{6}$ & $\mathbf{7}$ & $\mathbf{8}$ & $\mathbf{9}$ & $\mathbf{1 0}$ \\
\hline $\mathbf{1}$ & - & & & & & & & & & \\
$\mathbf{2}$ & $92 \cdot 9$ & - & & & & & & & & \\
$\mathbf{3}$ & $93 \cdot 7$ & $94 \cdot 0$ & - & & & & & & \\
$\mathbf{4}$ & $91 \cdot 6$ & $91 \cdot 2$ & $92 \cdot 5$ & - & & & & & \\
$\mathbf{5}$ & $93 \cdot 0$ & $91 \cdot 9$ & $96 \cdot 7$ & $92 \cdot 1$ & - & & & & \\
$\mathbf{6}$ & $93 \cdot 8$ & $92 \cdot 1$ & $93 \cdot 7$ & $94 \cdot 5$ & $94 \cdot 0$ & - & & & & \\
$\mathbf{7}$ & $93 \cdot 5$ & $91 \cdot 3$ & $87 \cdot 1$ & $95 \cdot 5$ & $93 \cdot 2$ & $95 \cdot 0$ & - & & & \\
$\mathbf{8}$ & $94 \cdot 0$ & $93 \cdot 0$ & $97 \cdot 6$ & $91 \cdot 3$ & $96 \cdot 2$ & $93 \cdot 9$ & $93 \cdot 0$ & - & & \\
$\mathbf{9}$ & $93 \cdot 0$ & $92 \cdot 1$ & $93 \cdot 0$ & $94 \cdot 1$ & $93 \cdot 3$ & $97 \cdot 0$ & $94 \cdot 1$ & $92 \cdot 8$ & - & \\
$\mathbf{1 0}$ & $93 \cdot 9$ & $93 \cdot 7$ & $97 \cdot 7$ & $92 \cdot 5$ & $96 \cdot 5$ & $94 \cdot 5$ & $93 \cdot 1$ & $97 \cdot 0$ & $93 \cdot 9$ & - \\
$\mathbf{1 1}$ & $93 \cdot 3$ & $91 \cdot 0$ & $92 \cdot 0$ & $92 \cdot 9$ & $91 \cdot 9$ & $93 \cdot 8$ & $97 \cdot 5$ & $92 \cdot 8$ & $93 \cdot 1$ & $91 \cdot 9$ \\
\hline
\end{tabular}

Table 6. $16 \mathrm{~S}$ rDNA nucleotide sequence similarities (\%) in S. algae

S. algae strain: 1, ATCC $51192^{\mathrm{T}} ; 2$, IAM 14159; 3, ACAM 4733; 4, ATCC 51181; 5, T $\phi 8 ; 6,14.80-\mathrm{A} ; 7,189-\operatorname{tr} ; 8,68872$.

\begin{tabular}{|lcccccccc|}
\hline Strain & GenBank no. & $\mathbf{1}$ & $\mathbf{2}$ & $\mathbf{3}$ & $\mathbf{4}$ & $\mathbf{5}$ & $\mathbf{6}$ & $\mathbf{7}$ \\
\hline $\mathbf{1}$ & AF005249 & - & & & & & & \\
$\mathbf{2}$ & U91546 & $98 \cdot 7$ & - & & & & \\
$\mathbf{3}$ & AF00669 & $97 \cdot 7$ & $97 \cdot 9$ & - & & & \\
$\mathbf{4}$ & X81622 & $99 \cdot 6$ & $99 \cdot 1$ & $98 \cdot 1$ & - & & & \\
$\mathbf{5}$ & U91547 & $98 \cdot 8$ & $98 \cdot 8$ & $98 \cdot 7$ & $99 \cdot 3$ & - & & \\
$\mathbf{6}$ & U91554 & $99 \cdot 0$ & $99 \cdot 3$ & $98 \cdot 3$ & $99 \cdot 5$ & $99 \cdot 2$ & - & \\
$\mathbf{7}$ & U91554 & $96 \cdot 7$ & $97 \cdot 0$ & $96 \cdot 8$ & $97 \cdot 1$ & $97 \cdot 4$ & $97 \cdot 2$ & - \\
$\mathbf{8}$ & U91548 & $99 \cdot 3$ & $99 \cdot 1$ & $98 \cdot 4$ & $99 \cdot 7$ & $99 \cdot 3$ & $99 \cdot 5$ & $97 \cdot 1$ \\
\hline
\end{tabular}

type strains of 11 Shewanella species. The percentage of nucleotide substitutions in the sequences varied from $2 \cdot 5$ to $8.8 \%$ (Table 5 ). It should be noted that the pairs ' $S$. pealeana' $/ S$. gelidimarina, $S$. putrefaciens $/ S$. oneidensis and $S$. woodyi/S. hanedai had dissimilarities in their $16 \mathrm{~S}$ rDNA nucleotide sequences of only $2 \cdot 5-3 \cdot 0 \%$.
Variation in 16S rDNA sequences, generated in this study or retrieved from GenBank, among strains was examined for $S$. algae $(n=8), S$. putrefaciens $(n=7), S$. oneidensis $(n=8)$ and $S$. frigidimarina $(n=6)$. The relationships between $S$. algae strains as revealed by 16S rDNA sequences are depicted in Table 6. Although strains from various environmental, animal and clini- 
Table 7. 16S rDNA nucleotide sequence similarities (\%) in S. putrefaciens

S. putrefaciens strain: 1, ATCC $8071^{\mathrm{T}} ; 2$, NCIMB 12577; 3, MR-30; 4, ACAM 122; 5, ACAM

574.

\begin{tabular}{|lccccc|}
\hline Strain & GenBank no. & $\mathbf{1}$ & $\mathbf{2}$ & $\mathbf{3}$ & $\mathbf{4}$ \\
\hline $\mathbf{1}$ & X82133 & - & & & \\
$\mathbf{2}$ & $\mathrm{U} 91551$ & $99 \cdot 2$ & - & & \\
$\mathbf{3}$ & AF005255 & $98 \cdot 6$ & $98 \cdot 7$ & - & \\
$\mathbf{4}$ & $\mathrm{U} 39398$ & $99 \cdot 6$ & $99 \cdot 1$ & $98 \cdot 6$ & - \\
$\mathbf{5}$ & AF006670 & $99 \cdot 3$ & $98 \cdot 7$ & $97 \cdot 9$ & $99 \cdot 0$ \\
\hline
\end{tabular}

Table 8. 16S rDNA nucleotide sequence similarities (\%) in S. oneidensis

S. oneidensis strain: 1, ATCC 700550² ; LMG 2369; 3, SP-7; 4, SP-22; 5, SP-32; 6, ACAM 576; 7, MR-4; 8, MR-7; 9, MR-8.

\begin{tabular}{|lccccccccc|}
\hline Strain & GenBank no. & $\mathbf{1}$ & $\mathbf{2}$ & $\mathbf{3}$ & $\mathbf{4}$ & $\mathbf{5}$ & $\mathbf{6}$ & $\mathbf{7}$ & $\mathbf{8}$ \\
\hline $\mathbf{1}$ & AF005251 & - & & & & & & \\
$\mathbf{2}$ & AJ000213 & $98 \cdot 6$ & - & & & & & \\
$\mathbf{3}$ & AF039054 & $97 \cdot 6$ & $98 \cdot 2$ & - & & & \\
$\mathbf{4}$ & AF039055 & $97 \cdot 1$ & $97 \cdot 2$ & $98 \cdot 7$ & - & & & \\
$\mathbf{5}$ & AF039056 & $96 \cdot 0$ & $96 \cdot 6$ & $97 \cdot 3$ & $97 \cdot 3$ & - & & \\
$\mathbf{6}$ & AF006671 & $97 \cdot 2$ & $97 \cdot 7$ & $96 \cdot 5$ & $96 \cdot 3$ & $95 \cdot 3$ & - & \\
$\mathbf{7}$ & AF005252 & $97 \cdot 7$ & $97 \cdot 4$ & $96 \cdot 6$ & $95 \cdot 7$ & $95 \cdot 2$ & $95 \cdot 7$ & - & \\
$\mathbf{8}$ & AF005253 & $97 \cdot 4$ & $97 \cdot 5$ & $96 \cdot 8$ & $96 \cdot 4$ & $95 \cdot 3$ & $96 \cdot 2$ & $98 \cdot 6$ & - \\
$\mathbf{9}$ & AF005254 & $96 \cdot 9$ & $96 \cdot 9$ & $96 \cdot 2$ & $95 \cdot 8$ & $94 \cdot 7$ & $95 \cdot 7$ & $98 \cdot 1$ & $98 \cdot 9$ \\
\hline
\end{tabular}

Table 9. $16 \mathrm{~S}$ rDNA nucleotide sequence similarities (\%) in S. frigidimarina

S. frigidimarina strain: $1, \mathrm{ICO}_{0}^{\mathrm{T}}: 2, \mathrm{ICP} 1 ; 3, \mathrm{ICP} 4 ; 4, \mathrm{ICP} 12 ; 5, \mathrm{NCIMB} 400 ; 6, \mathrm{~A} 173$.

\begin{tabular}{|lcccccc|}
\hline Strain & GenBank no. & $\mathbf{1}$ & $\mathbf{2}$ & $\mathbf{3}$ & $\mathbf{4}$ & $\mathbf{5}$ \\
\hline $\mathbf{1}$ & U85906 & - & & & & \\
$\mathbf{2}$ & $\mathrm{U} 85903$ & $98 \cdot 9$ & - & & & \\
$\mathbf{3}$ & $\mathrm{U} 85905$ & $99 \cdot 6$ & $99 \cdot 1$ & - & & \\
$\mathbf{4}$ & $\mathrm{U} 85904$ & $98 \cdot 8$ & $98 \cdot 2$ & $98 \cdot 7$ & - & \\
$\mathbf{5}$ & Y13699 & $99 \cdot 3$ & $98 \cdot 3$ & $99 \cdot 1$ & $98 \cdot 3$ & - \\
$\mathbf{6}$ & $\mathrm{U} 85902$ & $99 \cdot 1$ & $98 \cdot 7$ & $99 \cdot 1$ & $98 \cdot 3$ & $98 \cdot 6$ \\
\hline
\end{tabular}

cal sources were sequenced (Table 1), all were quite homogeneous except for strain 189-tr which forms its own branch on the tree generated by the maximumlikelihood method (see Fig. 2). On the basis of their proximity to type strain ATCC $8071^{\mathrm{T}}$, the five strains shown in Table 7 were chosen as being representative of $S$. putrefaciens. Strains ATCC $8071^{\mathrm{T}}$, NCIMB 12577 and MR-30 were screened against the SP-1/SP-2r primer set and generated the expected amplicon. Strain NCTC 10695, which was formerly classified as Pseudomonas rubescens and recently renamed $S$. putrefaciens, was the most highly divergent of the group with similarities of $96 \cdot 3-98 \cdot 1 \%$. Further $16 \mathrm{~S}$ rDNA analysis of the NCTC 10695 strain with recently established $S$. baltica revealed high similarity between them $(97 \cdot 3 \%)$.

A group of strains isolated from Oneida Lake (NY, USA), the Black Sea, the Southern Ocean and some clinical strains, although somewhat heterogeneous in 16S rDNA sequence (94.7-98.9\% similarities) does appear to form a cluster (Table 8). Within this cluster, several subgroups appear. The group of environmental isolates collectively known as the MR strains (Myers \& Nealson, 1988; Nealson et al., 1991) and the clinical isolates partition into two groups, while ACAM 576 remains distinct. The $16 \mathrm{~S}$ rDNA similarities between the six strains of $S$. frigidimarina are shown in Table 9. 


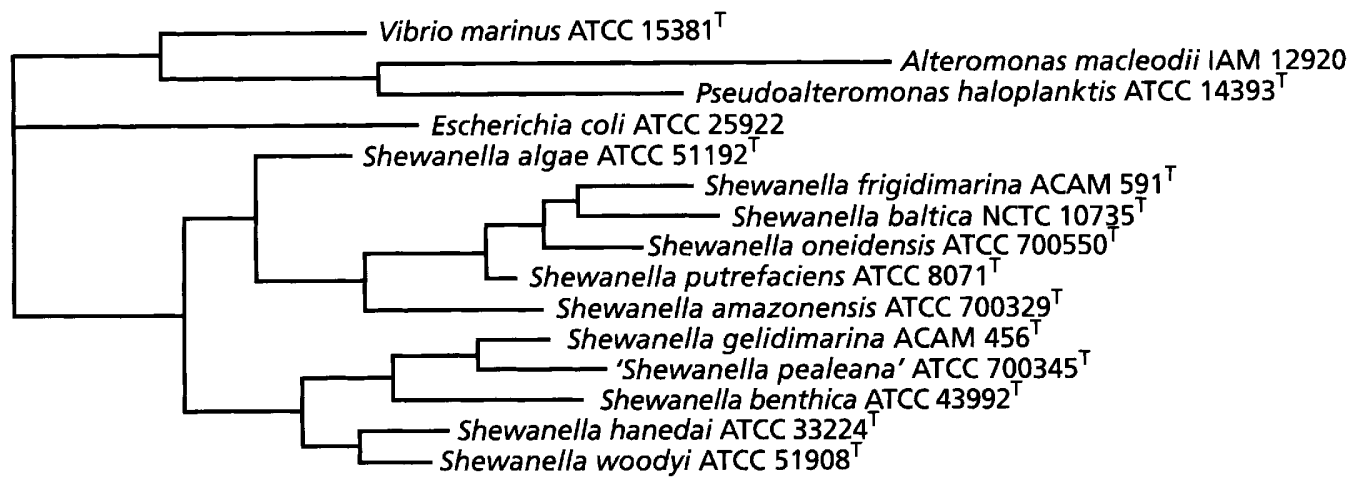

$0 \cdot 10$

Fig. 1. Phylogenetic tree including type strains of Shewanella based on $16 \mathrm{~S}$ rDNA sequence comparison by maximumlikelihood analysis.

This group forms a tight cluster, including one strain (NCIMB 400) which was formerly designated $S$. putrefaciens and has been renamed as $S$. frigidimarina (Reid \& Gordon, 1999).

A phylogenetic tree based on type strain $16 \mathrm{~S}$ rDNA sequences is shown in Fig. 1. The branching order of the 16S rDNA-based tree shows two distinct clusters corresponding to halophilic (' $S$. pealeana', $S$. gelidimarina, $S$. benthica, $S$. hanedai and $S$. woodyi) and halotolerant (S. algae, S. amazonensis, S. putrefaciens, $S$. frigidimarina and $S$. oneidensis) Shewanella groupings. The $16 \mathrm{~S}$ rDNA sequences of 47 strains from various sources (Table 1) were aligned and a neighbour-joining phylogenetic tree was constructed (Fig. 2). $16 \mathrm{~S}$ rDNA analysis indicates that the luminous species, $S$. hanedai and $S$. woodyi, form a group that is independent of the others in which $S$. woodyi ATCC $51908^{\mathrm{T}}$ branches most deeply of all. $S$. benthica, ' $S$. pealeana' and $S$. gelidimarina also form a distinct independent group. In this phylogeny, the $S$. algae group forms a distinct clade with the exception of strain 189-tr. S. putrefaciens, S. oneidensis, S. baltica and $S$. frigidimarina occupy a position adjoining $S$. amazonensis.

The clinical strains of $S$. oneidensis (SP-7, SP-22 and SP-32) along with $S$. oneidensis ATCC $700550^{\mathrm{T}}$ and ACAM 576 form a single group. The other three strains of $S$. oneidensis (MR-4, MR-7 and MR-8) comprise a distinct cluster. Among strains that were until recently called $S$. putrefaciens, three distinct clusters are noticed. They are: type strain ATCC $8071^{\mathrm{T}}$ cluster, $S$. baltica cluster and $S$. oneidensis cluster. Apparently these clusters correspond to Owen's hybridization groups I, II and III, respectively. However, NCTC 10695, which is the reference strain for Owen's group I, formed a cluster with $S$. baltica (Owen's group II). Although the strain ATCC 8073 (Owen's group III) appeared to form a cluster with the S. oneidensis group, strain 8073 branches most deeply among the others in the group. In addition, 16S rDNA nucleotide sequence dissimilarities are very high $(5.6 \%)$ between strains 8073 and ATCC $700550^{\mathrm{T}}$. Furthermore, the strain LMG 2369 (synonym of ATCC 8073 ) showed only $95.4 \%$ similarity in its $16 \mathrm{~S}$ rDNA sequences with ATCC 8073 . Because of these inconsistencies in Owen's hybridization grouping and recent classification of $S$. putrefaciens based on $16 \mathrm{~S}$ rDNA sequencing, a detailed DNA-DNA hybridization study is necessary to unearth the problem, if any, by including as many strains as possible.

(ii) gyrB sequence analysis. The $1.2 \mathrm{~kb}$ nucleotide sequences of the $\operatorname{gyr} B$ gene covering base positions 274-1525 (E. coli numbering, accession number P06982), were determined for ten Shewanella type strains. The percentage of nucleotide substitutions in the $g y r B$ genes varied from 12.7 to $27.3 \%$ (Table 10 ), whereas the percentage of substitutions in the amino acid sequences was $7 \cdot 2-20 \cdot 6 \%$. Among halophilic shewanellae, the range of $g y r B$ substitutions was $16-21 \%$, whereas the halotolerant strains exhibited greater heterogeneity (14-23\%).

One of the major conclusions drawn from this work is that the species $S$. putrefaciens needs to be better defined. Our first suspicions in this regard derived from an unexpected result in a molecular probing experiment. A primer set (SP-1/SP-2r) was designed to specifically recognize the gyrB sequence of $S$. putrefaciens type strain ATCC $8071^{\mathbf{T}}$. As predicted, the primer set failed to produce the $422 \mathrm{bp}$ amplicon when checked against 77 other species, including members of the genera Shewanella, Vibrio, Alteromonas, Deleya, Marinomonas and some representative of enteric bacteria (data not shown). When the PCR primer set was tested against the type strains of all ten known shewanellae (Fig. 3), a 422 bp amplicon was generated only for $S$. putrefaciens. The universal gyr $B$ primer set (UP-1/UP$2 r$ ) was used as a control and generated the predicted $1.2 \mathrm{~kb}$ PCR product for every organism tested in this study. When the primer set was tested against 100 


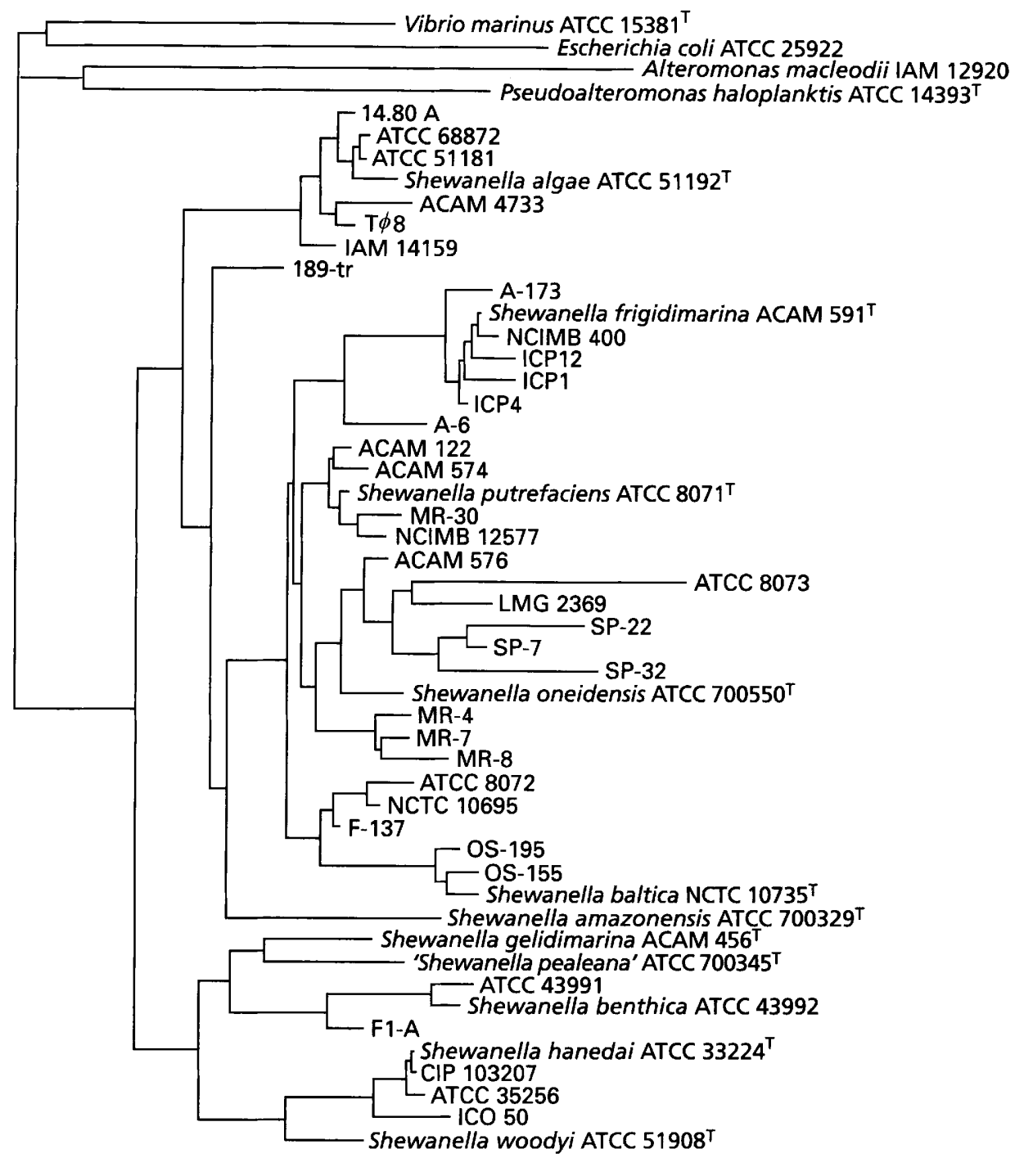

$0 \cdot 10$

Fig. 2. Phylogenetic tree including various strains of Shewanella based on 165 rDNA sequence comparison by maximumlikelihood analysis.

putative $S$. putrefaciens isolates from a variety of sources, 23 strains produced no amplicon. Of the 73 strains that showed a $S$. putrefaciens-specific amplicon, 19 strains, as well as 23 that were negative for the PCR product, were selected for $1.2 \mathrm{~kb}$ gyr $B$ gene sequencing. Of the subset for which the amplicon was generated, DNA sequence analysis revealed a close phylogenetic relationship between these strains and $S$. putrefaciens type strain ATCC $8071^{\mathrm{T}}$. In the case of those which failed to generate the PCR product, all could be reassigned to the known species $S$. algae or represented novel species within the genus Shewanella (S. amazonensis and $S$. oneidensis), thus verifying the utility of the probe for the identification of $S$. putrefaciens and suggesting that the name $S$. putrefaciens must be applied more critically. The primer set established here may then be used as a convenient and highly specific diagnostic tool for the identification of $S$. putrefaciens. Questions resulting from these experiments became the point of departure for the remainder of the study.

Variation in $\operatorname{gyr} B$ sequences among strains was examined for $S$. algae $(n=6), S$. putrefaciens $(n=19)$ and $S$. oneidensis $(n=8)$. The relationships between $S$. algae strains as revealed by $\operatorname{gyr} B$ sequences are depicted in Table 11. Although three strains each from environmental and clinical sources were sequenced, no patterns were observed except for between ATCC 51181 and the clinical isolates.

Dissimilarity among the 19 strains of $S$. putrefaciens 
Table 10. gyrB nucleotide sequence similarities (\%) among known Shewanella species

Shewanella species: 1, S. algae ATCC $51192^{\mathrm{T}} ; 2$, . amazonensis ATCC 700329 $; 3$, S. benthica ATCC $43992^{\mathrm{T}} ; 4$, S. frigidimarina ACAM 591 ${ }^{\mathrm{T}} ; 5$, S. gelidimarina ACAM 456 ${ }^{\mathrm{T}} ; 6, S$. hanedai ATCC $33224^{\mathrm{T}} ; 7$, S. oneidensis ATCC $700550^{\mathrm{T}} ; 8$, 'S . pealeana' ATCC $700345^{\mathrm{T}} ; 9, S$. putrefaciens ATCC $8071^{\mathrm{T}} ; 10, S$. woodyi ATCC $51908^{\mathrm{T}}$.

\begin{tabular}{|lccccccccc|}
\hline Species & $\mathbf{1}$ & $\mathbf{2}$ & $\mathbf{3}$ & $\mathbf{4}$ & $\mathbf{5}$ & $\mathbf{6}$ & $\mathbf{7}$ & $\mathbf{8}$ & $\mathbf{9}$ \\
\hline $\mathbf{1}$ & - & & & & & & & & \\
$\mathbf{2}$ & $80 \cdot 5$ & - & & & & & & & \\
$\mathbf{3}$ & $75 \cdot 2$ & $77 \cdot 9$ & - & & & & & \\
$\mathbf{4}$ & $74 \cdot 3$ & $76 \cdot 3$ & $77 \cdot 1$ & - & & & & \\
$\mathbf{5}$ & $73 \cdot 3$ & $76 \cdot 1$ & $80 \cdot 1$ & $80 \cdot 8$ & - & & & \\
$\mathbf{6}$ & $74 \cdot 4$ & $77 \cdot 4$ & $83 \cdot 6$ & $80 \cdot 4$ & $87 \cdot 3$ & - & & \\
$\mathbf{7}$ & $76 \cdot 3$ & $77 \cdot 9$ & $77 \cdot 8$ & $79 \cdot 1$ & $79 \cdot 3$ & $79 \cdot 9$ & - & & \\
$\mathbf{8}$ & $72 \cdot 7$ & $75 \cdot 3$ & $78 \cdot 7$ & $79 \cdot 3$ & $79 \cdot 7$ & $83 \cdot 2$ & $76 \cdot 8$ & - & \\
$\mathbf{9}$ & $77 \cdot 1$ & $79 \cdot 1$ & $81 \cdot 0$ & $81 \cdot 8$ & $81 \cdot 1$ & $82 \cdot 6$ & $85 \cdot 4$ & $78 \cdot 9$ & - \\
$\mathbf{1 0}$ & $73 \cdot 5$ & $74 \cdot 2$ & $80 \cdot 7$ & $74 \cdot 7$ & $79 \cdot 2$ & $82 \cdot 4$ & $78 \cdot 6$ & $79 \cdot 2$ & $77 \cdot 5$ \\
\hline
\end{tabular}

(a)

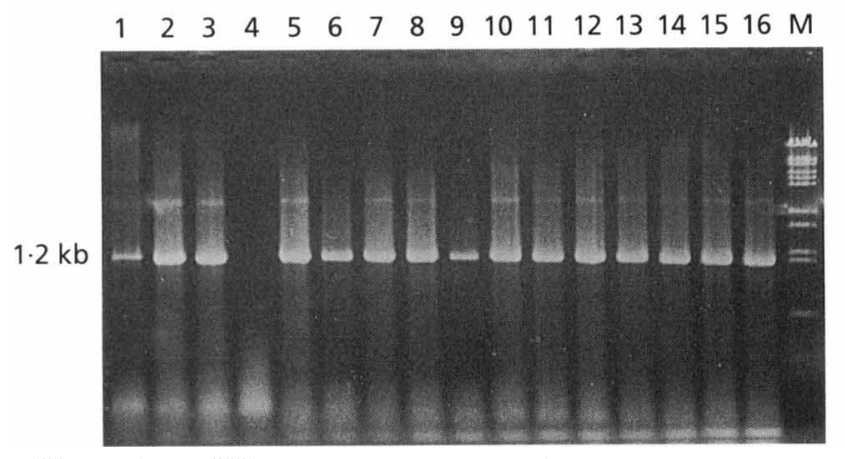

(b)

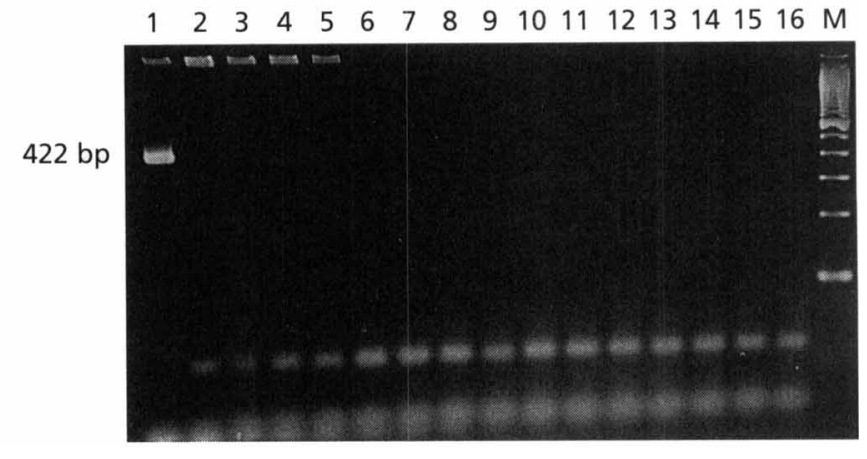

Fig. 3. Sensitivity of SP-1 and SP-2r PCR primers for the amplification of the S. putrefaciens-specific amplicon. (a) $1.2 \mathrm{~kb}$ gyrB fragment; (b) 422 bp S. putrefaciens-specific fragment. Lanes: M, DNA ladder; 1 , S. putrefaciens ATCC $8071^{\top}$; 2 , S. algae ATCC 51181; 3, S. amazonensis ATCC 700329 ; 4, bacterial DNA-free PCR mixture (negative control); 5 , S. benthica ATCC $43992^{\top} ; 6$, S. frigidimarina ACAM 594; 7, 5. gelidimarina ACAM 456 $; 8$, S. hanedai ATCC $33224^{\top} ; 9$, S. oneidensis $700550^{\top}$; 10 , 'S. pealeana' ATCC $700345^{\top}$; 11 , S. woodyi ATCC $51908^{\mathrm{T}}$; 12, E. coli ATCC 25992; 13, Vibrio parahaemolyticus ATCC $17802^{\top}$; 14, Vibrio marinus ATCC $15381^{\top}$; 15, Alteromonas macleodii ATCC 27126 ${ }^{\top}$; and 16 , Pseudoalteromonas haloplanktis ATCC $14393^{\top}$.

Table 11. gyrB nucleotide sequence similarities (\%) in S. algae

S. algae strain: 1, ATCC 51192 ; 2, ATCC 51181; 3, BCM-8; 4, SP-1; 5, SP-5; 6, SP-8.

\begin{tabular}{|lcccccc|}
\hline Strain & GenBank no. & $\mathbf{1}$ & $\mathbf{2}$ & $\mathbf{3}$ & $\mathbf{4}$ & $\mathbf{5}$ \\
\hline $\mathbf{1}$ & AF005686 & - & & & & \\
$\mathbf{2}$ & AF005691 & $90 \cdot 9$ & - & & & \\
$\mathbf{3}$ & AF005687 & $96 \cdot 5$ & $91 \cdot 1$ & - & & \\
$\mathbf{4}$ & AF005688 & $96 \cdot 4$ & $90 \cdot 0$ & $95 \cdot 1$ & - & \\
$\mathbf{5}$ & AF005689 & $96 \cdot 0$ & $89 \cdot 3$ & $93 \cdot 6$ & $97 \cdot 2$ & - \\
$\mathbf{6}$ & AF005690 & $95 \cdot 0$ & $88 \cdot 6$ & $92 \cdot 8$ & $96 \cdot 0$ & $98 \cdot 0$ \\
\hline
\end{tabular}


Table 12. gyrB nucleotide sequence similarities (\%) in S. putrefaciens

S. putrefaciens strain: 1, ATCC $8071^{\mathrm{T}} ; 2$, ATCC 8072; 3, BC-1; 4, CE-1; 5, CE-10; 6, CG-1; 7, CG-3; 8, DLM-1; 9, DLM-2; 10, DLM-13; 11, LMP-1; 12, LMP-9; 13, LW-1; 14, NCIMB 12577; 15, MR-30; 16, SP-10; 17, WAB-1; 18, 1 M-1; 19 , 7M-1.

\begin{tabular}{|c|c|c|c|c|c|c|c|c|c|c|c|c|c|c|c|c|c|c|c|}
\hline Strain & GenBank no. & 1 & 2 & 3 & 4 & 5 & 6 & 7 & 8 & 9 & 10 & 11 & 12 & 13 & 14 & 15 & 16 & 17 & 18 \\
\hline 1 & AF005669 & - & & & & & & & & & & & & & & & & & \\
\hline 2 & AF005670 & $91 \cdot 0$ & - & & & & & & & & & & & & & & & & \\
\hline 3 & AF005684 & $88 \cdot 2$ & $90 \cdot 4$ & - & & & & & & & & & & & & & & & \\
\hline 4 & AF005676 & $88 \cdot 3$ & $89 \cdot 6$ & 87.0 & - & & & & & & & & & & & & & & \\
\hline 5 & AF005677 & $87 \cdot 3$ & $89 \cdot 2$ & $86 \cdot 3$ & 98.5 & - & & & & & & & & & & & & & \\
\hline 6 & $\mathrm{AF} 005671$ & $91 \cdot 2$ & 93.6 & $92 \cdot 5$ & $90 \cdot 4$ & $91 \cdot 3$ & - & & & & & & & & & & & & \\
\hline 7 & AF005672 & $89 \cdot 7$ & 93.6 & $91 \cdot 3$ & $89 \cdot 6$ & $90 \cdot 0$ & 95.9 & - & & & & & & & & & & & \\
\hline 8 & AF005678 & $92 \cdot 4$ & $92 \cdot 8$ & 91.7 & $89 \cdot 6$ & $88 \cdot 3$ & 95.5 & $93 \cdot 2$ & - & & & & & & & & & & \\
\hline 9 & AF005679 & $93 \cdot 2$ & 93.8 & $92 \cdot 1$ & $90 \cdot 7$ & $89 \cdot 4$ & $95 \cdot 9$ & 93.5 & 97.2 & - & & & & & & & & & \\
\hline 10 & AF005680 & $93 \cdot 6$ & $93 \cdot 8$ & $92 \cdot 4$ & $90 \cdot 4$ & $89 \cdot 4$ & $95 \cdot 9$ & $94 \cdot 0$ & 97.1 & 98.8 & - & & & & & & & & \\
\hline 11 & AF005673 & $91 \cdot 2$ & $95 \cdot 0$ & $90 \cdot 9$ & $89 \cdot 9$ & $90 \cdot 1$ & $95 \cdot 1$ & $94 \cdot 3$ & $93 \cdot 3$ & $94 \cdot 2$ & $94 \cdot 3$ & - & & & & & & & \\
\hline 12 & AF005674 & $91 \cdot 2$ & $95 \cdot 6$ & $91 \cdot 1$ & $90 \cdot 4$ & $91 \cdot 2$ & $96 \cdot 5$ & $95 \cdot 1$ & 93.4 & $94 \cdot 6$ & $94 \cdot 5$ & $98 \cdot 3$ & - & & & & & & \\
\hline 13 & AF005683 & $88 \cdot 5$ & $90 \cdot 5$ & $97 \cdot 1$ & $87 \cdot 5$ & 86.9 & 93.2 & 91.4 & 91.8 & 93.0 & 93.0 & 91.2 & 91.2 & - & & & & & \\
\hline 14 & $\mathrm{AF} 014948$ & 97.5 & 92.0 & $88 \cdot 6$ & $89 \cdot 1$ & 87.9 & 91.6 & $90 \cdot 1$ & 92.3 & 92.9 & $93 \cdot 1$ & $92 \cdot 1$ & $92 \cdot 0$ & $89 \cdot 0$ & - & & & & \\
\hline 15 & AF005675 & $92 \cdot 0$ & $95 \cdot 1$ & 91.7 & $89 \cdot 6$ & $89 \cdot 4$ & 95.4 & 93.6 & $94 \cdot 1$ & $95 \cdot 9$ & $96 \cdot 2$ & 94.7 & 95.4 & $92 \cdot 1$ & $92 \cdot 8$ & - & & & \\
\hline 16 & AF039057 & 97.6 & $91 \cdot 6$ & $88 \cdot 6$ & $89 \cdot 1$ & 87.9 & $91 \cdot 7$ & $90-1$ & 91.9 & $92 \cdot 5$ & $92 \cdot 7$ & $91 \cdot 7$ & $91 \cdot 7$ & 88.7 & $97 \cdot 1$ & $92 \cdot 3$ & - & & \\
\hline 17 & AF005685 & 87.5 & 88.9 & $96 \cdot 5$ & $86 \cdot 4$ & 85.8 & $91 \cdot 4$ & $89 \cdot 7$ & $90 \cdot 9$ & 91.9 & $92 \cdot 1$ & 89.7 & 89.9 & $95 \cdot 5$ & 88.0 & $90-9$ & $87 \cdot 4$ & - & \\
\hline 18 & AF005681 & $88 \cdot 6$ & 89.9 & 94.9 & 86.6 & 85.9 & 91.0 & $89 \cdot 3$ & 91.7 & $92 \cdot 4$ & 92.4 & $90 \cdot 9$ & $90 \cdot 6$ & $94 \cdot 6$ & 88.7 & 91.0 & $88 \cdot 6$ & $94 \cdot 0$ & - \\
\hline 19 & AF 005682 & 88.9 & $90 \cdot 3$ & 96.7 & 87.5 & $86 \cdot 8$ & 92.7 & 90.2 & 91.6 & 92.6 & $92 \cdot 6$ & $91 \cdot 3$ & $91 \cdot 3$ & $97 \cdot 8$ & 89.0 & $92 \cdot 1$ & $89 \cdot 2$ & $95 \cdot 6$ & 96.0 \\
\hline
\end{tabular}

Table 13. gyrB nucleotide sequence similarities in S. oneidensis

S. oneidensis strain: 1 , ATCC 700550 $; 2$, MR-4; 3, MR-7; 4, DLM-7; 5, SP-3; 6, SP-7; 7, SP$22 ; 8$, SP-32.

\begin{tabular}{|lcccccccc|}
\hline Strain & GenBank no. & $\mathbf{1}$ & $\mathbf{2}$ & $\mathbf{3}$ & $\mathbf{4}$ & $\mathbf{5}$ & $\mathbf{6}$ & $\mathbf{7}$ \\
\hline $\mathbf{1}$ & AF005694 & - & & & & & & \\
$\mathbf{2}$ & AF005695 & $90 \cdot 4$ & - & & & & & \\
$\mathbf{3}$ & AF005696 & $86 \cdot 9$ & $94 \cdot 4$ & - & & & & \\
$\mathbf{4}$ & AF005697 & $92 \cdot 0$ & $87 \cdot 6$ & $86 \cdot 1$ & - & & & \\
$\mathbf{5}$ & AF005698 & $89 \cdot 8$ & $89 \cdot 8$ & $88 \cdot 1$ & $86 \cdot 9$ & - & & \\
$\mathbf{6}$ & AF039060 & 86.9 & $88 \cdot 4$ & $90 \cdot 0$ & $86 \cdot 8$ & $92 \cdot 3$ & - & \\
$\mathbf{7}$ & AF039058 & $87 \cdot 3$ & $89 \cdot 0$ & $90 \cdot 5$ & $87 \cdot 2$ & $92 \cdot 6$ & $99 \cdot 0$ & - \\
$\mathbf{8}$ & AF039059 & $87 \cdot 3$ & $88 \cdot 9$ & $90 \cdot 5$ & $87 \cdot 3$ & $92 \cdot 9$ & $98 \cdot 6$ & $99 \cdot 1$ \\
\hline
\end{tabular}

examined was $1 \cdot 2-12.0 \%$ (Table 12 ). The strain isolated from the inner harbour of Milwaukee (CG-1) showed the greatest consensus, being $\geqslant 90 \%$ homologous to all of the others. The isolates from Lake Michigan (DLM strains) and Lower Mystic Pond, MA, USA (LMP strains) displayed at least $90 \%$ identity with $16-17$ of the others. Wisconsin isolates (LW-1, 1M-1 and 7M-1) were homologous to 11-13 strains. Among the strains tested, the Antarctic strains (CE-1 and CE-10) exhibited the highest dissimilarity $(8 \cdot 7-14.2 \%)$ when their gyrB sequences were compared to others. Strains SP-10 (clinical isolate), NCIMB 12577 (oilfield isolate) and ATCC $8071^{\mathrm{T}}$ (type strain), although derived from very different source materials, formed a defined cluster, exhibiting a similarity of $>97.5 \%$. The dissimilarities in the gyr $B$ sequences of the group $S$. oneidensis are shown in Table 13. Although a large within-group variation was observed $(1 \cdot 0-13 \cdot 9 \%)$, no definite patterns with respect to the sources of these isolates was apparent.
The relative phylogenetic positions occupied by each of the Shewanella type strains, based on $\operatorname{gyr} B$ nucleotide sequences, are shown in Fig. 4. An unrooted tree was generated by the maximum-likelihood method (Fig. 4). The results indicate that $S$. putrefaciens and $S$. oneidensis, as well as $S$. algae and $S$. amazonensis, form distinct clusters. The branching order of the $g y r B$ based tree differs somewhat from that of a similar tree based on $16 \mathrm{~S}$ rDNA nucleotide sequences. The $\operatorname{gyr} B$ sequences of 41 strains from various sources were aligned and the resulting unrooted tree diverged into two major branches corresponding to the halophilic and halotolerant species (Fig. 5). The halotolerant strains, $S$. putrefaciens $(n=19), S$. oneidensis $(n=8), S$. algae $(n=6)$ and $S$. amazonensis clustered into four distinct groups of perfect integrity with regard to species. Within the $S$. putrefaciens group, five clusters are evident and at least partially consistent with geographical groupings. These clusters include: the deep-branching Antarctic isolates (CE-1 and CE-10); 


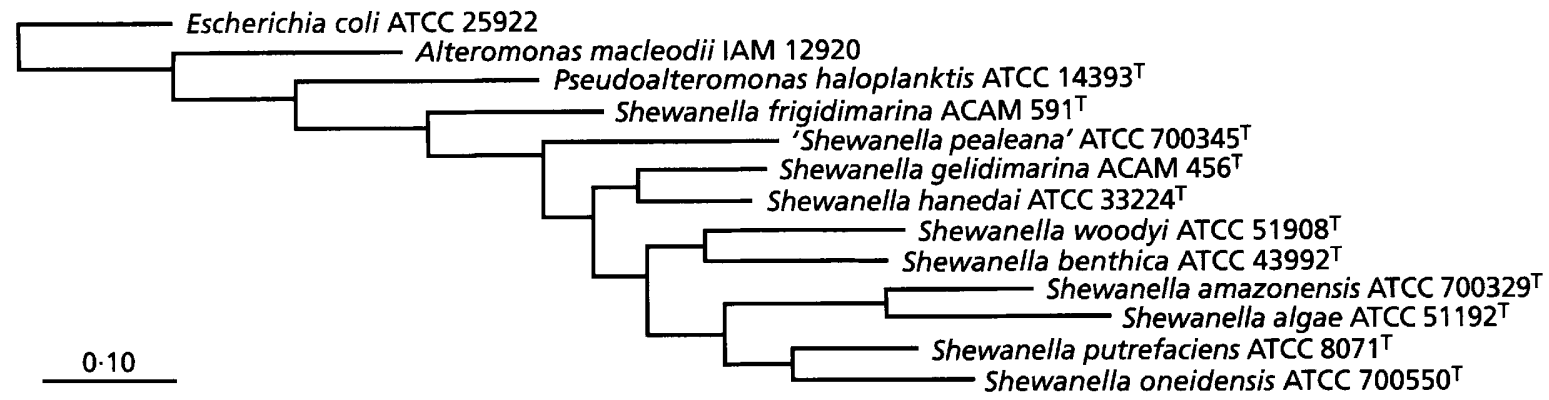

Fig. 4. Phylogenetic tree including type strains of Shewanella based on gyrB nucleotide sequence comparison by maximum-likelihood analysis.

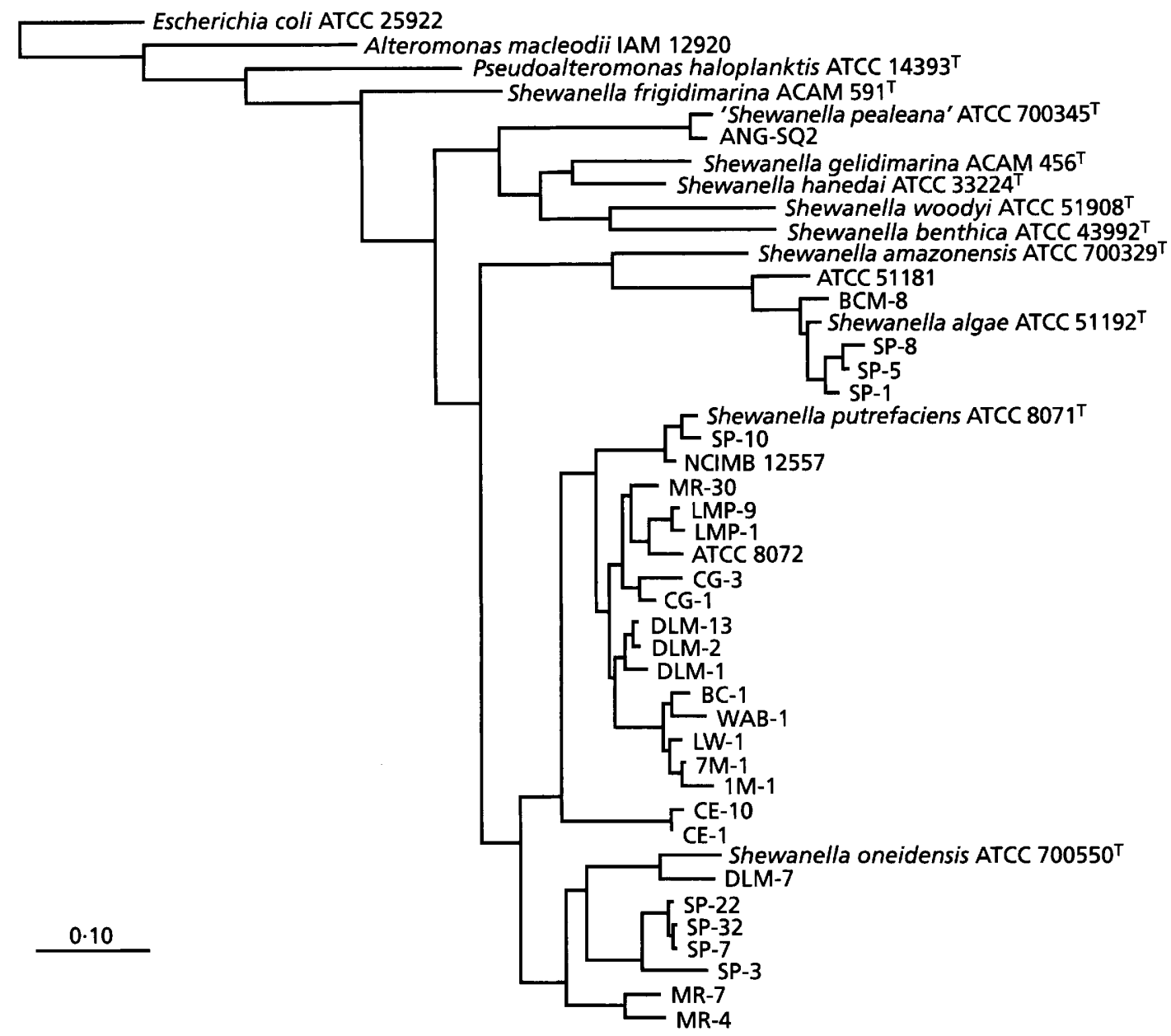

Fig. 5. Phylogenetic tree including various strains of Shewanella based on gyrB nucleotide sequence comparison by maximum-likelihood analysis.

the type strain cluster, comprised ATCC $8071^{\mathrm{T}}$, NCIMB 12557 and one clinical strain, SP-10; the ATCC 8072 cluster containing strains isolated from the inner harbour of Milwaukee, Lower Mystic Pond, MA, and Green Bay, WI, USA; an off-shore Lake Michigan cluster (DLM-1, DLM-2, DLM-13); and a cluster derived from agricultural streams of Wisconsin and Indiana (1M-1, 7M-1, LW-1, WAB-1, BC-1). Among the $S$. oneidensis isolates, strains ATCC $700550^{\mathrm{T}}$ and DLM-7 form a cluster, MR-4 and MR-7 form another and the clinical isolates, SP-3, SP-7, SP22 and SP-32, form yet another. The $S$. algae group 
Table 14. DNA-DNA hybridization (\%) of various Shewanella species

Shewanella species: 1, S. algae ATCC $51192^{\mathrm{T}} ; 2, S$. amazonensis ATCC $700329^{\mathrm{T}} ; 3, S$. benthica ATCC $43992^{\mathrm{T}} ; 4$, $S$. hanedai ATCC $33224^{\mathrm{T}} ; 5, S$. oneidensis ATCC $700550^{\mathrm{T}} ; 6$, 'S. pealeana' ATCC $700345^{\mathrm{T}} ; 7, S$. putrefaciens ATCC $8071^{\mathrm{T}}$; 8, S. woodyi ATCC $51908^{\mathrm{T}}$.

\begin{tabular}{|lccccccc|}
\hline Species & $\mathbf{1}$ & $\mathbf{2}$ & $\mathbf{3}$ & $\mathbf{4}$ & $\mathbf{5}$ & $\mathbf{6}$ & $\mathbf{7}$ \\
\hline $\mathbf{1}$ & - & & & & & & \\
$\mathbf{2}$ & $30 \cdot 1$ & - & & & & & \\
$\mathbf{3}$ & $23 \cdot 0$ & $31 \cdot 2$ & - & & & & \\
$\mathbf{4}$ & $15 \cdot 0$ & $29 \cdot 3$ & $31 \cdot 3$ & - & & & \\
$\mathbf{5}$ & $17 \cdot 6$ & $40 \cdot 3$ & $30 \cdot 5$ & $24 \cdot 4$ & - & & \\
$\mathbf{6}$ & $37 \cdot 6$ & $27 \cdot 3$ & $29 \cdot 4$ & $26 \cdot 4$ & $20 \cdot 4$ & - & \\
$\mathbf{7}$ & $16 \cdot 6$ & $42 \cdot 7$ & $24 \cdot 6$ & $15 \cdot 7$ & $35 \cdot 7$ & $21 \cdot 5$ & - \\
$\mathbf{8}$ & $25 \cdot 6$ & $24 \cdot 6$ & $33 \cdot 5$ & $27 \cdot 4$ & $39 \cdot 0$ & $23 \cdot 0$ & $29 \cdot 4$ \\
\hline
\end{tabular}

clusters tightly, with the exception of strain ATCC $51181(\mathrm{BrY})$, which bifurcates at some distance from the others. The other major branch, comprising the halophiles, can be divided into five distinct groups.

(iii) DNA-DNA hybridization. DNA-DNA hybridization was performed to examine relatedness between the eight species considered here. The percentage similarities of Shewanella strains examined are given in Table 14. None of the values were above the $70 \%$ similarity value which would place the strains within the same species (Stackebrandt \& Goebel, 1994). Among the halophilic shewanellae, the DNA reassociation percentage range was $23 \cdot 0-33 \cdot 5 \%$, with $S$. benthica and $S$. woodyi being most closely related $(33.5 \%)$ and the two luminous species, $S$. hanedai and $S$. woodyi, being less closely related $(27 \cdot 4 \%)$. Among the halotolerant strains, DNA-DNA hybridization values varied between 16.6 and $42.7 \%$. DNA-DNA similarity values between $S$. putrefaciens and $S$. oneidensis were $35.7 \%$; S. algae and S. amazonensis, 30.1\% ; and $S$. putrefaciens and $S$. algae, 16.6\%.

\section{DISCUSSION}

As discussed previously, Farmer (1992) divided the family Vibrionaceae into four major genera, Aeromonas, Photobacterium, Plesiomonas and Vibrio, and a dozen minor genera, including Shewanella. In spite of this humble treatment, the shewanellae represent bacteria of economic significance. Perhaps because these organisms have been studied largely on the basis of applied microbiology, the phylogeny of this group may have been neglected.

Until recently, bacterial taxonomists have had little option but to rely on patterns of physiological traits to classify their subjects. Colony appearance, characteristic smells, pigmentation and other attributes of organisms in culture can be of dubious value in terms of useful taxonomic insight and can potentially lead to the assignment of misguided associations between loosely affiliated or unrelated organisms. While it is possible to systematize any group of isolates on the basis of phenotypic characters, the comparative value of a given trait or group of traits over another remains difficult to assess. Even when consensus provides a set of biochemical criteria with which to define a given organism, in the absence of exhaustive quality assurance measures, variations in the approaches used for the culture and testing of isolates can produce very different results, potentially leading to spurious identifications.

For example, Shewanella species display an ability to adjust their membrane phospholipid fatty acid content depending on whether they are grown under aerobic or anaerobic conditions (Nichols et al., 1997). Esterlinked phospholipid fatty acid patterns of strain ATCC $700550^{\mathrm{T}}$ were monitored over an $8 \mathrm{~h}$ incubation period under two sets of conditions: an aerobic to anaerobic transition and an anaerobic to aerobic one. The relative amounts of terminally branched saturated FAME increased by $13-25 \%$ when the organisms were shifted from an aerobic to anaerobic environment. This switch also resulted in a decrease in the relative percentage of the monounsaturated forms from 65 to $55 \%$. In the opposite case, anaerobic to aerobic transition, little change in either class of FAME was detected. Monounsaturated FAME remained at a relative percentage of $54 \%$ while a small increase, 21 to $26 \%$, in the terminally branched saturates was observed (data not shown). The occurrence of ubiquinones and menaquinones in the membranes of a number of the species of this genus (Lies et al., 1996) coincides with the ability of these organisms to proliferate under both aerobic and anaerobic conditions.

These differences clearly point out the need for standardized growth conditions for biomolecular analyses and make comparisons of data from different laboratories difficult. This is not meant to infer that phenotypic considerations have lost standing in the determination of taxonomic relationships. Indeed, the Ad Hoc Committee on the Reconciliation of Approaches to Bacterial Systematics concluded that phenotypic consistency must remain the bottom line in polyphasic taxonomy (Wayne et al., 1987). Rather, the limitations of classical phenotypic taxonomy argue for the inclusion of independent measures for the validation of bacterial relationships.

Although it is possible to differentiate all 11 shewanellae based on physiological traits, the required biochemical testing is labour intensive, costly and potentially prone to experimental error. Molecular methods are tacitly less susceptible to artefactual misinterpretation than culture-based approaches. With the advent of these techniques, a well-defined series of criteria for the designation of taxa now exist that function independently of sometimes phylogenetically arbitrary physiological and morphological boundaries. The basic unit of taxonomy is the species, 
which is defined as a group of strains, including the type strain, sharing $\geqslant 70 \%$ relatedness over the entire genome (Wayne et al., 1987). An extensive review of the literature by Stackebrandt \& Goebel (1994) revealed that organisms with less than $97 \%$ similarity over the 16S rRNA gene do not yield DNA reassociation values of more than $60 \%$; hence, rDNA sequence analysis may be used as a surrogate for DNA reassociation. On the other hand, rDNA similarity of greater than $97 \%$ does not necessarily indicate that any two isolates are of the same species. For example, although Vibrio parahaemolyticus and Vibrio alginolyticus show very high rDNA similarity (99.9\%; Ruimy et al., 1994), phenotypically they are easily distinguished and regarded as distinct species (Venkateswaran et al., 1989). Similarly, Bacillus cereus and Bacillus thuringiensis cannot be differentiated at the molecular level though the latter can be physiologically distinguished by virtue of its insecticidal crystal protein (Turnbull \& Kramer, 1991). For these reasons, any taxonomic scheme must show phenotypic as well as molecular consistency (Wayne et al., 1987).

At the time of submission, GenBank contained $3916 \mathrm{~S}$ rDNA sequences for organisms denoted as $S$. putrefaciens. Members of this rather heterogeneous group possessed sequence similarities as low as $94 \%$. For example, strains 189-tr, NCIMB 400 and ACAM 576, which are placed within $S$. putrefaciens $(95,96 \cdot$, $95.3 \%$ similarity) actually have higher similarities to $S$. algae $(96.7 \%)$, S. frigidimarina $(99.3 \%)$ and S. oneidensis $(97.2 \%)$, respectively. In accordance with the consensus molecular definition of the species (Wayne et al., 1987), we have defined the subset of strains within this group containing $97 \%$ or greater similarity to the type strain ATCC $8071^{\mathrm{T}}$ as legitimate $S$. putrefaciens.

Previously, Owen et al. (1978) reported the existence of four groups in $S$. putrefaciens based on the DNADNA reassociation values. $S$. putrefaciens ATCC $8071^{\mathrm{T}}, 8072$ and 8073 strains are representative of Owen's group I, II and III, respectively. Group IV is already defined as $S$. algae (Simidu et al., 1990). Group I strains that are highly related to the type strain ATCC $8071^{\mathbf{T}}$ are considered as the true $S$. putrefaciens. Ziemke et al. (1998) established $S$. baltica as a new species to represent group II. However, strain ATCC 8072 has low DNA-DNA reassociation value with the type strain of $S$. baltica NCTC $10735^{\mathrm{T}}(58 \%$; Owen et al., 1978). Additionally, in our study the gyrB primers specific for ATCC $8071^{\mathrm{T}}$ do amplify the $S$. putrefaciens-specific fragment with the DNA extracted from the ATCC 8072 strain. Since other strains from group II, including those now classified as $S$. baltica, have not been examined, it is not known whether these primers are specific for group I or also recognize group II strains, or whether ATCC 8072 should be reclassified as a group I strain.

No-one has reported any definite species belonging to Owen's proposed group III. However, Ziemke et al. (1998) cited in their recent publication that strain
LMG 2369 might represent group III. Our study showed that $S$. oneidensis has high $16 \mathrm{~S}$ rDNA similarities with LMG $2369(98 \cdot 6 \%)$ whereas the ATCC 8073 strain that represents group III had very low $16 \mathrm{~S}$ rDNA homologies with both LMG $2369(95.4 \%)$ and ATCC $700550^{\mathrm{T}}(94.4 \%)$ strains. The phylogenetic tree constructed by including these strains showed a single cluster with a deep branch for strain ATCC 8073. Since the NCIMB strain catalogue lists LMG 2369 as a synonym for ATCC 8073, it is unclear why the $16 \mathrm{~S}$ rDNA sequences for these strains are different and this also complicates the assignment of these strains to a given species or hybridization group. As a DNA-DNA reassociation study with $S$. oneidensis ATCC $700550^{\mathrm{T}}$ and LMG 2369 was not performed, it cannot be concluded here that $S$. oneidensis represents group III.

Owen et al. (1978) also claimed that DNA-DNA reassociation values are variable between the members of all four groups within the shewanellae and noted high reassociation values $(>80-100 \%)$ only for groups I and IV. In contrast, groups II and III showed ranges of $57-83 \%$ and $41-72 \%$, respectively. Because of these inconsistencies within the $S$. putrefaciens, Owen concluded that it is difficult to relate DNA relatedness to the taxonomic hierarchy of this species. While our approach is not based on the Owen groupings, we agree with the report of Owen's that DNA relatedness is not the decisive factor deciding the taxonomic hierarchy in $S$. putrefaciens. Further studies are warranted.

DNA-DNA hybridization was used to verify our assertion that each of the 11 groups described here deserves species status. Although $S$. oneidensis strains (formerly the MR group) have traditionally been placed within the species S. putrefaciens (Myers \& Nealson, 1988) and phenotypic data fail to reveal any major distinctions between them, DNA-DNA reassociation results $(35.7 \%)$ clearly indicate that these should be regarded as distinct. It should be noted that the recently reported luminous species $S$. woodyi exhibited $97.5 \%$ 16S rDNA sequence similarities with its luminous counterpart $S$. hanedai, whereas DNADNA reassociation and $\operatorname{gyr} B$ sequence similarities were 27.4 and $82.4 \%$, respectively. Although $S$. amazonensis and $S$. algae appear to be closely related phenotypically, they display a low level of DNA-DNA similarity $(30 \cdot 1 \%)$; whereas $S$. amazonensis and $S$. putrefaciens show the highest similarity of all $(42 \cdot 7 \%)$. While this manuscript was in proof, our recent DNA hybridization study revealed that ' $S$. pealana' ANG$\mathrm{SQ} 1^{\mathrm{T}}$ and $S$. gelidimarina ACAM $456^{\mathrm{T}}$ had only $25.3 \%$ similarity and deserve a separate species status (Leonardo et al., 1999).

The use of $\operatorname{gyr} B$ as a measure of bacterial relatedness has been established in the genera Pseudomonas, Acinetobacter (Yamamoto \& Harayama, 1995, 1996), Vibrio (Venkateswaran et al., 1998a), Bacillus and Clostridium (unpublished results). The base substitution frequency of $g y r B$ is much higher than that of the 16S rRNA gene, making it a more appropriate 
choice for differentiating close phylogenetic relationships (Ochman \& Wilson, 1987). When the gyrB sequences of $17 \mathrm{~S}$. putrefaciens isolates were compared, 121 out of 136 total combinations showed similarities of $\geqslant 90 \%$. A similar pattern was also noted for $S$. algae and thus we propose a species cut-off value of $90 \%$ for $g y r B$ sequences. Even though their $16 \mathrm{~S}$ rDNA similarities are inconclusive at $97 \%$, when the $g y r B$ criteria are applied to the $S$. putrefaciens/S. oneidensis, $S$. woodyi/S. hanedai and 'S. pealeana' /S. gelidimarina couples, similarities of 85,82 and $80 \%$ were noted, respectively. These values are below the $90 \%$ threshold, suggesting that $S$. putrefaciens, $S$. oneidensis, $S$. woodyi, S. hanedai, 'S. pealeana' and $S$. gelidimarina are indeed separate species. Similarly, even though the 16S rDNA similarity between $S$. baltica and ATCC $8071^{\mathrm{T}}$ is very high $(97.7 \%)$, the status of species is given to $S$. baltica (NCTC $10735^{\mathrm{T}}$ ) based on the low DNA relatedness between these two strains $(28 \%)$. Even so, there are still intergenic dissimilarities among group II strains (ATCC 8072 and $S$. baltica DNA relatedness is only $58 \%$ ).

The work at hand represents a comprehensive effort to impose a logical phylogenetic framework on the growing collection of Shewanella isolates. While it appears likely that additional isolates representing novel species will be discovered in the future, the 11 species considered here already indicate that this genus contains formerly unappreciated diversity. This study illustrates the utility of molecular and chemotaxonomic approaches for determining phylogenetic relationships in phenotypically ambiguous groups. It is possible to build upon the taxonomic foundations established by the polyphasic approach to design gene probes for the rapid and efficient screening of isolates.

\section{Reassignment of Shewanella putrefaciens MR-1 to Shewanella oneidensis sp. nov.}

Since its introduction in 1988, the metal-reducing strain MR-1 has been identified as $S$. putrefaciens on the basis of both conventional phenotypic taxonomy and chemotaxonomy. When 100 putative $S$. putrefaciens isolates were screened against the SP-1 and SP$2 \mathrm{r}$ gyr $B$ probes, no PCR amplification product was observed for 23 of the strains, including MR-1. The physiology and genetics of strain MR-1 are perhaps better studied than any of the other shewanellae (Myers \& Nealson, 1988). This led us to perform a phylogenetic analysis for this group.

The phylogenetic position of MR-1 was examined by the comparison of its $16 \mathrm{~S}$ rDNA sequence to those of all known eubacterial phyla (Woese, 1987). All phylogenetic analyses confirmed the placement of MR-1 within the $\gamma$-subclass of the Proteobacteria. The phylogenetic relationships of MR-1 were then analysed, and this study was repeated with several different subdomains of the $16 \mathrm{~S}$ rDNA sequence and bootstrapping analysis performed to avoid sampling artefacts. Both 16S rDNA and gyrB nucleotide sequences of MR-1 indicate that it shares a close phylogenetic relationship with the species Shewanella, Alteromonas and Vibrio.

Neighbour-joining, parsimony and maximum-likelihood analyses were then performed on this subgroup of bacteria, using several subdomains of the $16 \mathrm{~S}$ rDNA. The results of these analyses are summarized in Fig. 1 and Table 5. In all cases, MR-1 was most closely associated with members of the genus Shewanella. The 16S rDNA sequence of MR-1 was compared with the nine other Shewanella species for which 16S rDNA sequences are available in GenBank, and dissimilarities in their 16S rDNA nucleotide sequences are shown (Table 5). Very high variation $(9 \%)$ was noted between MR-1 and $S$. benthica ATCC $43992^{\mathrm{T}}$. Otherwise, the values were mostly between 3 and $7 \%$. The dissimilarity between MR-1 and S. frigidimarina ACAM $591^{\mathrm{T}}$ (U85906) was $3 \cdot 8 \%$ and that between MR-1 and $S$. putrefaciens ATCC $8071^{\mathrm{T}}$ (X81623) was $3 \%$. This $97 \%$ similarity between MR-1 and the $S$. putrefaciens type strain is insufficient to prove or disprove a species relationship.

Because the $\operatorname{gyr} B$ probe data failed to support a species relationship between MR-1 and $S$. putrefaciens and rDNA similarity data were inconclusive in this regard, DNA-DNA hybridization and $g y r B$ sequence analysis were carried out. Strain MR-1 showed DNA reassociation values of between 17.6 and $40 \%$ with the other species tested (Table 14). The percentage similarity of DNA between MR-1 and S. putrefaciens was only $36 \%$, well below the $70 \%$ threshold for the inclusion within a species (Stackebrandt \& Goebel, 1994).

The dissimilarities in the $\operatorname{gyr} B$ gene sequences of all 11 shewanellae along with MR-1 are given in Table 10. A phylogenetic tree based on $\operatorname{gyr} B$ nucleotide sequences is shown in Fig. 4. Unlike the situation with the $16 \mathrm{~S}$ rDNA, variation between $\operatorname{gyr} B$ genes was very high $(>20 \%)$. A very high variation $(22.7 \%)$ was noted between $S$. oneidensis and $S$. algae ATCC $51192^{\mathrm{T}}$. Unlike $16 \mathrm{~S}$ rDNA analysis, a clear conclusion could be drawn from $\operatorname{gyr} B$ sequence analysis. Although the $85 \%$ similarity seen between MR-1 and $S$. putrefaciens indicates a closer relationship than for any other pairs, this value is still well below the $90 \%$ species cut-off. Hence, strain MR-1 is distinct and deserves the status of species.

\section{Description of Shewanella oneidensis}

S. oneidensis (o.nei.da. M.L. n. oneidensis named after Oneida Lake, NY, USA, where the bacterium was isolated).

The cells of the type strain are rod-shaped. They are $2-3 \mu \mathrm{m}$ in length and $0.5-0.6 \mu \mathrm{m}$ in diameter, Gramnegative, facultatively anaerobic, polarly flagellated bacteria. Neither endospores nor capsules are formed. Colonies on LB agar medium are circular, smooth and convex with an entire edge, and beige to pinkish depending on age. Sodium ions are not essential for 
growth. Cells are able to grow at mesophilic temperatures. Optimal growth is observed at $30^{\circ} \mathrm{C}$. Cells are able to reduce nitrate to nitrite and nitrite to nitrous oxide. They exhibit cytochrome oxidase, catalase and gelatinase activities, and produce $\mathrm{H}_{2} \mathrm{~S}$ from thiosulfate. They do not haemolyse sheep erythrocytes and show weak growth at $\mathrm{NaCl}$ concentrations above $3 \%$. They utilize lactate, succinate and fumarate as sole carbon sources and reduce transition metal oxides ( $\mathrm{Fe}, \mathrm{Mn}, \mathrm{U})$ and elemental sulfur. Based on both $16 \mathrm{~S}$ rDNA and gyr $B$ nucleotide sequences, this bacterium belongs to the $\gamma$-subclass of the class Proteobacteria and is a member of the genus Shewanella. The type strain MR-1 (=ATCC 700550 $\left.{ }^{\mathrm{T}}\right)$ was isolated from sediments.

\section{ACKNOWLEDGEMENTS}

We are thankful to M. Janda for supplying clinical isolates; S. Rea for DNA of $S$. frigidimarina and $S$. gelidimarina; C. Wimpee for $S$. woodyi; L. Gram for various $S$. algae and $S$. putrefaciens data sets; G. Bergtrom for nucleotide sequence analyses; $\mathrm{H}$. Owen for the technical assistance with the electron microscopy; and $\mathrm{K}$. Reed for phylogenetic analyses. We also acknowledge contributions of $\mathrm{M}$. Leonardo, S. Sutton, B. Baker and V. Kasprzak for their technical assistance. This work was supported by grants from NASA (144-GH82) and Sea Grant (144-FP99) to K.H.N.

\section{REFERENCES}

Aguirre, A. A., Balazas, G. H., Zimmerman, B. \& Spraker, T. R. (1994). Evaluation of Hawaiian green turtles (Chelonia mydas) for potential pathogens associated with fibropapillomas. $J$ Wildl Dis 30, 8-15.

Akagawa-Matsushita, M., Itoh, T., Katayama, Y., Kuraishi, H. \& Yamasato, K. (1992). Isoprenoid quinone composition of some marine Alteromonas, Marinomonas, Deleya, Pseudomonas and Shewanella species. J Gen Microbiol 138, 2275-2281.

Baumann, P., Gauthier, M. J. \& Baumann, L. (1984). Genus Alteromonas Baumann, Baumann, Mandel and Allen, 1972, 418. In Bergey's Manual of Systematic Bacteriology, pp. 243-352. Edited by N. R. Krieg \& J. G. Holt. Baltimore: Williams \& Wilkins.

Bowman, J. P., McCammon, S. A., Nichols, D. S., Skerratt, J. H., Rea, S. M., Nichols, P. D. \& McMeekin, T. A. (1997). Shewanella gelidimarina sp. nov., and Shewanella frigidimarina sp. nov., novel Antarctic species with the ability to produce eicosapentaenoic acid $(20: 5 \omega 3)$ and grow anaerobically by dissimilatory Fe(III) reduction. Int J Syst Bacteriol 47, 1040-1047.

Brink, A. J., van Straten, A. \& van Rensburg, A. J. (1995). Shewanella (Pseudomonas) putrefaciens bacteremia. Clin Infect Dis 20, 1327-1332.

Cashion, P., Holder-Franklin, M. A., McCully, J. \& Franklin, M. (1977). A rapid method for the base ratio determination of bacterial DNA. Anal Biochem 81, 461-466.

Cole, R. M. \& Popkin, T. J. (1981). Electron microscopy. In Manual of Methods for General Bacteriology, pp. 34-51. Edited by P. Gerhardt, R. G. E. Murray, R. N. Costilaw, E. W. Nester, W. A. Wood, N. R. Krieg \& G. B. Phillips. Washington, DC: American Society for Microbiology.

Coyne, V. E., Pillidge, C. J., Sledjeski, D. D., Hori, H., Ortiz-Conde, B. A., Muir, D. G., Weiner, R. M. \& Colwell, R. R. (1989). Re- classification of Alteromonas colwelliana to the genus Shewanella by DNA-DNA hybridization, serology and 5S ribosomal RNA sequence data. Syst Appl Microbiol 12, 275-279.

De Ley, J., Cattoir, H. \& Reynaerts, A. (1970). The quantitative measurement of DNA hybridisation from renaturation rates. Eur J Biochem 12, 133-142.

Derby, H. A. \& Hammer, B. W. (1931). Bacteriology of butter. IV. Bacteriological studies of surface taint butter. Iowa Agric Exp Stn Res Bull 145, 387-416.

Edgell, D. R. \& Doolittle, W. F. (1997). Archaea and the origin(s) of DNA replicon proteins. Cell 89, 995-998.

Escara, J. F. \& Hutton, J. R. (1980). Thermal stability and renaturation of DNA in dimethylsulphoxide solutions: acceleration of renaturation rate. Biopolymers 19, 1315-1327.

Farmer, J. J., III (1992). The family Vibrionaceae. In The Prokaryotes, pp. 2939-2951. Edited by M. P. Starr, H. Stolp, H. G. Trüper, A. Balows \& H. G. Schlegel. Berlin: Springer.

Felsenstein, J. (1990). PHYLIP manual version 3.3. University Herbarium, University of California, Berkeley, CA, USA.

Fonnesbech-Vogel, B., Jorgensen, K., Christensen, H., Olsen, J. E. \& Gram, L. (1997). Differentiation of Shewanella putrefaciens and Shewanella alga on the basis of whole-cell protein profiles, ribotyping, phenotypic characterization, and 16S rRNA gene sequence analysis. Appl Environ Microbiol 63, 2189-2199.

Fox, G. E., Wisotzkey, J. D. \& Jurtshuk, P., Jr (1992). How close is close: 16S rRNA sequence identity may not be sufficient to guarantee species identity. Int J Syst Bacteriol 42, 166-170.

Gilmour, D. (1990). Halotolerant and halophilic microorganisms. In Microbiology of Extreme Environments, pp. 147-177. Edited by C. Edwards. Milton Keynes: Open University Press.

Huß, V. A. R., Festl, H. \& Schleifer, K. H. (1983). Studies on the spectrophotometric determination of DNA hybridization from renaturation rates. Syst Appl Microbiol 4, 184-192.

Jahnke, K.-D. (1992). BASIC computer program for evaluation of spectroscopic DNA renaturation data from GILFORD SYSTEM 2600 spectrophotometer on a PC/XT/AT type personal computer. J Microbiol Methods 15, 61-73.

Jensen, M. J., Tebo, B. M., Baumann, P., Mandel, M. \& Nealson, K. H. (1980). Characterization of Alteromonas hanedai (sp. nov.), a nonfermentative luminous species of marine origin. Curr Microbiol 3, 311-315.

Johnson, J. L. (1981). Genetic characterization. In Manual of Methods for General Bacteriology, pp. 450-472. Edited by P. Gerhardt, R. G. E. Murray, R. N. Costilaw, E. W. Nester, W. A. Wood, N. R. Krieg \& G. B. Phillips. Washington, DC: American Society for Microbiology.

Jorgensen, B. R. \& Huß, H. H. (1989). Growth and activity of Shewanella putrefaciens isolated from spoiling fish. Int $J$ Food Microbiol 9, 51-62.

Kostka, J. E., Stucki, J. W., Nealson, K. H. \& Wu, J. (1996). Reduction of structural $\mathrm{Fe}$ (III) in smectite by a pure culture of Shewanella putrefaciens strain MR-1. Clays and Clay Minerals 44, 522-529.

Lee, J. V., Gibson, D. M. \& Shewan, J. M. (1977). A numerical taxonomic study of some Pseudomonas-like marine bacteria. $J$ Gen Microbiol 98, 439-451.

Leonardo, M. R., Moser, D. P., Barbieri, E., Brantner, C. A., Paster, B. J., Stackebrandt, E. \& Nealson, K. H. (1999). Shewanella pealeana sp. nov., a member of a microbial community associated with the accessory nidamental gland of the squid Loligo pealei. Int J Syst Bacteriol (in press). 
Lies, D. P., Moser, D. P., Sano, H., Nishijima, M. \& Sakai, M. (1996). Types and levels of isoprenoid quinones synthesized under various growth conditions for strains of Shewanella putrefaciens. In Abstracts of the 96 th General Meeting of the American Society for Microbiology, pp. 547. Washington, DC: American Society for Microbiology.

Lovely, D. R. \& Phillips, E. J. (1988). Novel mode of microbial energy metabolism: organic carbon oxidation coupled to dissimilatory reduction of iron or manganese. Appl Environ Microbiol 51, 683-689.

MacDonell, M. T. \& Colwell, R. R. (1985). Phylogeny of the Vibrionaceae and recommendation for two new genera, Listonella and Shewanella. Syst Appl Microbiol 6, 171-182.

Makemson, J. C., Fulayfil, N. R., Landry, W., Van Ert, L. M., Wimpee, C. F., Widder, E. A. \& Case, J. F. (1997). Shewanella woodyi (sp. nov.), a new exclusively respiratory luminous bacterium isolated from the Alboran Sea. Int J Syst Bacteriol 47, 1034-1039.

Mesbah, M., Premachandran, U. \& Whitman, W. B. (1989). Precise measurement of the $\mathrm{G}+\mathrm{C}$ content of deoxyribonucleic acid by high-performance liquid chromatography. Int J Syst Bacteriol 39, 159-167.

Miller, J. H. (1972). Experiments in Molecular Genetics. Cold Spring Harbor, NY: Cold Spring Harbor Laboratory.

Moser, D. P. \& Nealson, K. H. (1996). Growth of the facultative anaerobe Shewanella putrefaciens by elemental sulfur reduction. Appl Environ Microbiol 62, 2100-2105.

Moule, A. L. \& Wilkinson, S. G. (1987). Polar lipids, fatty acids, and isoprenoid quinones of Alteromonas putrefaciens (Shewanella putrefaciens). Syst Appl Microbiol 9, 192-198.

Myers, C. R. \& Nealson, K. H. (1988). Bacterial manganese reduction and growth with manganese oxide as the sole electron acceptor. Science 240, 1319-1321.

Nealson, K. H. \& Saffarini, D. (1994). Iron and manganese anaerobic respiration. Annu Rev Microbiol 48, 311-343.

Nealson, K. H., Myers, C. R. \& Wimpee, B. B. (1991). Isolation and identification of manganese-reducing bacteria and estimates of microbial Mn(IV)-reducing potential in the Black Sea. Deep Sea Res 38, S907-S920.

Nichols, D. S., Nichols, P. D., Russell, N. J., Davies, N. W. \& McMeekin, T. A. (1997). Polyunsaturated fatty acids in the psychrophilic bacterium Shewanella gelidimarina ACAM $456^{\mathrm{T}}$ : molecular species analysis of major phospholipids and biosynthesis of eicosapentaenoic acid. Biochim Biophys Acta 1347, 164-176.

Nishijima, M., Araki-Sakai, M. \& Sano, H. (1997). Identification of isoprenoid quinones by frit-FAB liquid chromatography-mass spectrometry for the chemotaxonomy of microorganisms. $J$ Microbiol Methods 28, 113-122.

Nozue, H., Hayashi, T., Hashimoto, Y., Ezaki, T., Hamazaki, K., Ohwada, K. \& Terawaki, Y. (1992). Isolation and characterization of Shewanella alga from human clinical specimens and emendation of the description of $S$. alga Simidu et al., 1990, 335. Int $J$ Syst Bacteriol 42, 628-634.

Ochman, H. \& Wilson, A.C. (1987). Evolution in bacteria: evidence for a universal substitution rate in cellular genomes. $J$ Mol Evol 26, 74-86.

Owen, R. J., Legros, R. M. \& Lapage, S. P. (1978). Base composition, size, and sequence similarities of genome deoxyribonucleic acids from clinical isolates of Pseudomonas putrefaciens. J Gen Microbiol 104, 127-138.

Perry, K. A., Kostka, J. E., Luther, G. W., III \& Nealson, K. H.
(1993). Mediation of sulfur speciation by a Black Sea facultative anaerobe. Science 259, 801-803.

Petrovskis, E. A., Vogel, T. M. \& Adriaens, P. (1994). Effects of electron acceptors and donors on transformation of tetrachloromethane by Shewanella putrefaciens MR-1. FEMS Microbiol Lett 121, 357-364.

Ringelberg, D. B., Townsend, G. T., DeWeerd, K. A., Suflita, J. M. \& White, D. C. (1994). Detection of the anaerobic dechlorinating microorganism Desulfomonile tiedjei in environmental matrices by its signature lipopolysaccharide branched-long-chain hydroxy fatty acids. FEMS Microbiol Ecol 14, 9-18.

Reid, G. A. \& Gordon, E. H. J. (1999). Phylogeny of marine and freshwater Shewanella: reclassification of Shewanella putrefaciens NCIMB 400 as Shewanella frigidimarina. Int J Syst Bacteriol 49, 189-191.

Ruimy, R., Breittmayer, V., Elbaze, P., Lafay, B., Boussemart, O., Gauthier, M. \& Christen, R. (1994). Phylogenic analysis and assessment of the genera Vibrio, Photobacterium, Aeromonas, and Plesiomonas deduced from small subunit rRNA sequences. Int J Syst Bacteriol 44, 416-426.

Sambrook, J., Fritsch, E. F. \& Maniatis, T. (1989). Molecular Cloning : a Laboratory Manual, 2nd edn. Cold Spring Harbor, NY: Cold Spring Harbor Laboratory.

Semple, K. M. \& Westlake, D. W. S. (1987). Characterization of iron reducing Alteromonas putrefaciens strains from oil field fluids. Can J Microbiol 35, 925-931.

Shewan, J. M. (1977). The bacteriology of fresh and spoiling fish and the biochemical changes induced by bacterial action. In Proceedings of the Conference on Handling, Processing and Marketing of Tropical Fish, pp. 51-66. London: Tropical Products Institute.

Shewan, J. M., Hobbs, G. \& Hodgkiss, W. (1960). A determinative scheme for the identification of certain genera of Gram-negative bacteria with special reference to Pseudomonadaceae. J Appl Bacteriol 23, 379-390.

Simidu, U., Kita-Tsukamoto, K., Yasumoto, T. \& Yotsu, M. (1990). Taxonomy of four marine bacterial strains that produce tetrodotoxin. Int J Syst Bacteriol 40, 331-336.

Stackebrandt, E. \& Goebel, B. M. (1994). A place for DNA-DNA reassociation and $16 \mathrm{~S}$ rRNA sequence analysis in the present species definition in bacteriology. Int $J$ Syst Bacteriol 44, 846-849.

Stenstrom, I.-M. \& Molin, G. (1990). Classification of spoilage flora of fish, with special reference to Shewanella putrefaciens. $J$ Appl Bacteriol 68, 601-618.

Strunk, O. \& Ludwig, W. (1995). ARB - a software environment for sequence data. Department of Microbiology, Technical University of Munich, Munich, Germany.

Swofford, D. (1990). PAUP: phylogenetic analysis using parsimony, version 3.0. Computer program distributed by the Illinois Natural History Survey, Champaign, IL, USA.

Trüper, H. G. \& de' Clari, L. (1997). Taxonomic note: Necessary correction of specific epithets formed as substantives (nouns) 'in apposition'. Int J Syst Bacteriol 47, 908-909.

Turnbull, P. C. B. \& Kramer, J. M. (1991). Bacillus. In Manual of Clinical Microbiology, 5th edn, pp. 296-303. Edited by A. Balows, W. J. Hausler, K. L. Herrmann, H. D. Isenberg \& H. J. Shadomy. Washington, DC: American Society for Microbiology.

Venkateswaran, K., Nakano, H., Okabe, T., Takayama, K., Matsuda, O. \& Hashimoto, H. (1989). Occurrence and distribution of Vibrio spp., Listonella spp., and Clostridium 
botulinum in the Seto Inland Sea of Japan. Appl Environ Microbiol 55, 559-567.

Venkateswaran, K., Dohmoto, N. \& Harayama, S. (1998a). Cloning and nucleotide sequence of $\mathrm{gyrB}$ gene of Vibrio parahaemolyticus and its application in detection of the pathogen in shrimp. Appl Environ Microbiol 64, 681-687.

Venkateswaran, K., Dollhopf, M. E., Aller, R., Stackebrandt, E. \& Nealson, K. H. (1998b). Shewanella amazonensis sp. nov., a novel metal-reducing facultative anaerobe from Amazonian shelf muds. Int J Syst Bacteriol 48, 965-972.

Wayne, L. G., Brenner, D. J., Colwell, R. R. \& 9 other authors (1987). International Committee on Systematic Bacteriology. Report of the ad hoc committee on reconciliation of approaches to bacterial systematics. Int J Syst Bacteriol 37, 463-464.

Weiner, R. M., Coyne, V. E., Brayton, P., West, P. A. \& Raiken, S. F. (1988). Alteromonas colwelliana sp. nov., an isolate from oyster habitats. Int J Syst Bacteriol 38, 240-244.
West, P. A. \& Colwell, R. R. (1984). Identification and classification overview. In Vibrios in the Environment, pp. 285-363. Edited by R. R. Colwell. New York: Wiley.

Woese, C. R. (1987). Bacterial evolution. Microbiol Rev 51, 221-271.

Yamamoto, S. \& Harayama, S. (1995). PCR amplification and direct sequencing of $g y r B$ genes with universal primers and their application to the detection and taxonomic analysis of Pseudomonas putida strains. Appl Environ Microbiol 61, 1104-1109.

Yamamoto, S. \& Harayama, S. (1996). Phylogenetic analysis of Acinetobacter strains on the nucleotide sequences of $g y r B$ genes and on the amino acid sequences of their products. Appl Environ Microbiol 46, 506-511.

Ziemke, F., Hofle, M. G., Lalucat, J. \& Rossello-Mora, R. (1998). Reclassification of Shewanella putrefaciens Owen's genomic group II as Shewanella baltica sp. nov. Int $J$ Syst Bacteriol 48 , 179-186. 